\title{
The Effects of Ultrasonic Disintegration as a Function of Waste Activated Sludge Characteristics and Technical Conditions of Conducting the Process-Comprehensive Analysis
}

\author{
Malwina Tytła \\ Institute of Environmental Engineering, Polish Academy of Sciences, 34 M. Skłodowskiej-Curie St., \\ 41-819 Zabrze, Poland; malwina.tytla@ipis.zabrze.pl; Tel.: +48-32-271-6481 (ext. 135)
}

Received: 11 September 2018; Accepted: 18 October 2018; Published: 20 October 2018

\begin{abstract}
A comprehensive analysis of the effects obtained in the process of ultrasonic disintegration (UD) of waste activated sludge (WAS), was conducted. Sludge samples were collected periodically from Central Wastewater Treatment Plant (WWTP) in Gliwice (Poland) and disintegrated in the two ultrasonic devices of different construction and technical parameters, i.e., WK-2010 (A) and ultrasonic washer (B). The experiments were performed under a constant energy supply per sludge volume $\mathrm{E}_{\mathrm{V}}=160 \mathrm{kWh} \cdot \mathrm{m}^{-3}$. The direct and technological effects, i.e., after UD and anaerobic digestion (AD) were investigated, respectively. Statistical analysis showed that characteristics and parameters of the WAS, which affects the magnitude of the direct effects create the following sequence: TS (total solids), VS (volatile solids), $\Delta \mathrm{T}$ (temperature increase) $>$ EPS (extracellular polymeric substances) $>$ SCOD (soluble chemical oxygen demand) > CST (capillary suction time) $>\mathrm{N}_{\mathrm{TOT}}$ (total nitrogen), $\mathrm{P}_{\text {TOт }}$ (total phosphorus) $>\mathrm{pH}$. Whereas, in the case of technological effects, the above sequence was as follows: TS, VS $>$ CST $>\mathrm{N}_{\text {TOT }}, \mathrm{P}_{\text {TOT }}>\mathrm{pH}$. Ultrasonic disintegration of WAS prior to AD increased total biogas production (from $13.0 \%$ to $19.7 \%$ ) and reduced the content of TS (from $4.1 \%$ to $8.2 \%$ ) and VS (5.8\% to $9.5 \%)$ in comparison to the control sample. This confirms the usefulness of ultrasonic disintegration as an effective method of sludge digestion intensification. The obtained results showed that changes in the characteristics of WAS have a significant impact on the magnitude of the effects of ultrasonic disintegration, especially TS, VS, $\triangle \mathrm{T}$, EPS, SCOD and CST. Concluding, it can be inferred that the most promising conditions for ultrasonic pretreatment conducted under constant energy supply per sludge volume, are: low power, long sonication time, large surface area of the emitter, and high increase of sludge temperature while conducting the process.
\end{abstract}

Keywords: waste activated sludge; ultrasonic disintegration; disintegration effects; sludge characteristics; wastewater treatment plant

\section{Introduction}

The development of new technologies and growing effectiveness of biological wastewater treatment observed in recent years, can be mainly accounted to the implementation of the European Council Directive [1] concerning urban wastewater treatment, which led to an increase in the amount of sewage sludge production [2,3]. The significance of the abovementioned issue is even more pressing due to the hazards which sludge may pose to the environment and the economy. It is estimated that by the year 2020, the amount of sludge produced in European Union (EU) countries will reach 12,997,000 $\mathrm{Mg}_{\mathrm{TS}}$, in which 950,000 $\mathrm{Mg}_{\mathrm{TS}}$ would be in Poland alone [4]. Moreover, the costs associated with sludge treatment and its disposal may constitute as much as $65 \%$ of the total operating costs of Wastewater Treatment Plant (WWTP) [5]. Therefore, it is necessary to introduce 
methods for intensifying anaerobic digestion, which is the most commonly applied process in sludge treatment, that enable sludge stabilization and mass reduction, improve its dewaterability and ensure hygienization [6,7]. Among these methods, we can distinguish disintegration. Nowadays, it is one of the most important environmental issues.

There are different types of disintegration techniques, i.e., mechanical (ultrasonic disintegration, homogenizations), thermal (hydrolysis-low and high temperature), chemical (hydrolysis with oxygen, ozone, sodium hydroxide) and biological (with application of enzymes) [8,9]. Currently, mechanical methods are the most effective and commonly used, especially ultrasonic disintegration, which is based on the cavitation phenomenon $[2,10]$. Ultrasonic disintegration shortens the hydrolytic phase, i.e., the rate-limiting step of anaerobic digestion (AD), and increases the efficiency of the process $[2,6]$. Moreover, ultrasonic disintegration (UD) increases the solubility of the organic compounds (by disrupting the sludge floc and cells), leading to a release of intracellular materials available for living organisms, which can be used as a substrate in the subsequent steps of anaerobic digestion $[8,11]$. It must be emphasized, that ultrasonic disintegration is one of the most secure and environmentally friendly methods of anaerobic sludge digestion intensification, to which mainly waste activated sludge (WAS) is subjected due to the difficulty in its decomposing [8]. The advantages of sludge UD are: lack of byproducts or use of additional reagents and possibility to intervene during the process conducting $[11,12]$. We can distinguish two types of ultrasonic disintegration effects: direct and technological. The direct effects are observed after ultrasonic pretreatment, whereas the technological during further sludge treatment, i.e., anaerobic digestion $[11,13]$. The obtained effects are described by appropriate indicators of disintegration, i.a. disintegration degree $\left(\mathrm{DD}_{\mathrm{COD}}\right)$ [14], etc. The direct effects are monitored based on the physicochemical changes of sludge characteristics (parameters) before and after pretreatment, i.a. $\mathrm{pH}[11,15]$, concentration of soluble chemical oxygen demand (SCOD) $[3,16]$, biogenic substances $[17,18]$ and extracellular polymeric substances $[9,19]$ in sludge supernatant, capillary suction time (CST) $[7,20]$ or microscopy examination of a flocs disruption $[5,21]$. In the case of anaerobic digestion the expected effects are: increase in biogas production, total solids (TS) and volatile solids (VS) reduction, as well as dewatering ability improvement $[10,13]$. The effects of sludge pretreatment are also influence by operating parameters of the process conducting, i.a. technical construction of ultrasonic device, frequency $(\mathrm{f})$, the amount of energy supplied per sludge volume $\left(\mathrm{E}_{\mathrm{V}}\right)$ or total solids content $\left(\mathrm{E}_{\mathrm{S}}\right)$, ultrasonic density $\left(\mathrm{U}_{\mathrm{D}}\right)$ and intensity $\left(\mathrm{U}_{\mathrm{I}}\right)$, sonication time $(\mathrm{t})$ and process temperature $(\mathrm{T})[18,22,23]$.

Therefore, taking into account the number of factors, which may have an impact on a magnitude of disintegration effects, a comprehensive analysis and selection of the most important sludge characteristics (parameters) and technical conditions of the process conducting are necessary. This is particularly important due to the fact that it is still unknown why in the similar conditions of sludge sonication, different effects are obtained. However, it is important to emphasize that there are no two identical sludges-their characteristics change over time. Therefore, it is important to carry out the ultrasonic disintegration in a cyclical manner, i.e., at an appropriate time intervals, which will allow observing changes in sludge characteristics and indicate the main parameters, that have the greatest impact on the obtained effects.

The aims of this study were: (a) to evaluate direct and technological effects based on the values of selected indicators and optical microscopy examination; (b) to determine sludge characteristics (parameters) and technical conditions of the process conducting, having the greatest impact on the direct and technological effects; (c) to conduct a comprehensive analysis of the disintegration effects, with including periodically changes of WAS characteristics and technical conditions of conducting the process, using selected statistical tests. 


\section{Materials and Methods}

\subsection{Sludge Collection and Analysis}

The WAS samples were collected once a month over a 7-months period of time, starting from July 2013 up to January 2014. Sludge samples after mechanical thickening were collected from the advanced biological Central Wastewater Treatment Plant in Gliwice (Poland, Central Europe). The digested sludge (inoculum) was taken from a full scale anaerobic digester (mesophilically operated) in the same WWTP and used only in order to conduct anaerobic digestion. The collected sludge samples were stored in polypropylene tubes at $4{ }^{\circ} \mathrm{C}$ before further analysis. The operational parameters of the WWTP are reported in Table 1.

Table 1. The operational parameters of the Wastewater Treatment Plant.

\begin{tabular}{ccc}
\hline Parameter $^{{ }^{1}}$ & Unit & Value \\
\hline Population equivalent (PE) & - & 155,009 \\
Average flow (Q) & $\mathrm{m}^{3} \cdot \mathrm{d}^{-1}$ & 31,913 \\
Hydraulic retention time (HRT) of sludge in anaerobic digester & $\mathrm{d}$ & 33 \\
\hline
\end{tabular}

${ }^{1}$ Data for the year 2017 obtained from the Central WWTP in Gliwice.

In order to determine the changes of sludge samples characteristics-before and after UD/AD, selected parameters were considered, i.e., $\mathrm{pH}$, SCOD, $\mathrm{N}_{\mathrm{TOT}}$ (total nitrogen), $\mathrm{P}_{\mathrm{TOT}}$ (total phosphorus), proteins and carbohydrates concentrations, CST, flocs disruption (microscopic examination; at 100× magnification), TS and VS content, as well as volume and composition of the evolved biogas. Prior and after UD or AD, sludge samples were centrifuged for $30 \mathrm{~min}$ at $20,000 \mathrm{rpm}\left(18^{\circ} \mathrm{C}\right)$ and subjected to vacuum filtration throughout membrane filters ( $0.45 \mu \mathrm{m}$; Chemland, Gyeonggi-do, Korea) [24]. Sludge prepared in the following manner was measured for: SCOD, $\mathrm{N}_{\text {TOT }}$ and $\mathrm{P}_{\text {TOT }}$ concentrations. In order to determine the concentration of extracellular polymeric substances the thermally extraction was conducted. At the beginning, WAS sample was centrifuged at $2000 \times \mathrm{g}$ for $20 \mathrm{~min}$. The residual sludge pellet was resuspended in the distilled water right to the original volume and placed into the water bath $\left(\right.$ at $80^{\circ} \mathrm{C}$ ) for $1 \mathrm{~h}$. After incubation sludge was separated from extract by centrifugation at $2000 \times$ $\mathrm{g}$ and $4500 \times$ g over 20 min each time, respectively [25,26]. In the obtained extracts the concentration of proteins and carbohydrates, were measured. The albumin bovine (Acros Organics) and glucose $(\mathrm{POCH})$, were used as a standard solutions. Moreover, the measurements of: $\mathrm{pH}, \mathrm{TS}, \mathrm{VS}, \mathrm{CST}$ and sludge temperature increase $(\Delta \mathrm{T})$, as well as microscopic examination, were determined only in the sludge samples. Whereas, the biogas volume and composition $\left(\mathrm{CH}_{4}, \mathrm{CO}_{2}, \mathrm{H}_{2} \mathrm{~S}\right)$ were measured during sludge anaerobic digestion. The list of methods/devices used for sludge samples analysis, before and after UD and/or AD processes (including type of the obtained effects) are shown in Table 2.

Table 2. The list of methods used in this study.

\begin{tabular}{cccc}
\hline Parameter & Methods/Devices & Reference & Type of Effects \\
\hline $\mathrm{pH}$ & $\begin{array}{c}\text { Electrometric method; } \\
\text { Multi HQ40D (Hach Lange) }\end{array}$ & PN-EN 12176:2004 [27] & Direct; Technological \\
\hline TS & Weight method (at 105 $\left.{ }^{\circ} \mathrm{C}\right)$ & PN-EN 12880:2004 [28] & Technological; \\
\hline VS & Weight method (at 550 $\left.{ }^{\circ} \mathrm{C}\right)$ & PN-EN 12879:2004 [29] & Technological \\
\hline $\mathrm{SCOD}_{0} ; \mathrm{SCOD}_{\mathrm{UD}}$ & $\begin{array}{c}\text { Potassium dichromate method; } \\
\text { measurement tests LCI 400, LCK } \\
\text { 014 (Hach Lange); } \\
\text { UV-VIS DR 5000 }\end{array}$ & ISO 15705:2002 [30] & Direct \\
\hline $\mathrm{N}_{\mathrm{TOT}}$ & $\begin{array}{c}\text { Potassium oxidation method } \\
\text { measurement tests LCK 238 (Hach } \\
\text { Lange); UV-VIS DR 5000 }\end{array}$ & ISO 11905-1:1997 [31] & Direct, Technological \\
\hline
\end{tabular}


Table 2. Cont

\begin{tabular}{|c|c|c|c|}
\hline Parameter & Methods/Devices & Reference & Type of Effects \\
\hline $\mathrm{P}_{\text {TOT }}$ & $\begin{array}{c}\text { Ammonium molybdate method; } \\
\text { measurement tests LCK } 350 \text { (Hach } \\
\text { Lange); UV-VIS DR } 5000\end{array}$ & ISO 6878:2004 [32] & Direct, Technological \\
\hline Proteins & $\begin{array}{l}\text { Folina-Ciocalteau reagent; } \\
\text { UV-VIS DR } 5000\end{array}$ & Lowry et al., 1951 [33] & Direct \\
\hline Carbohydrates & $\begin{array}{l}\text { Phenol-Sulphuric acid reaction } \\
\text { method; } \\
\text { UV-VIS DR } 5000\end{array}$ & Dubois et al., 1956 [34] & Direct \\
\hline CST & $\begin{array}{c}\text { Quantity measurement; } \\
\text { Capillary suction timer (Envolab) }\end{array}$ & $\begin{array}{l}\text { PN-EN 14701-1:2007 } \\
{[35]}\end{array}$ & Direct, Technological \\
\hline$\Delta \mathrm{T}$ & $\begin{array}{c}\text { Quantity measurement; } \\
\text { Digi-Sense (Cole-Parmer) }\end{array}$ & - & Direct \\
\hline Flocs disruption & $\begin{array}{c}\text { Optical microscopy; } \\
\text { Optical microscope (MOTIC } \\
\text { BA400) }\end{array}$ & - & Direct \\
\hline Biogas production & $\begin{array}{l}\text { Quantitative measurement; } \\
\text { MULTITEC } 540 \text { gauge (Sewerin) }\end{array}$ & - & Technological \\
\hline Biogas composition & $\begin{array}{c}\text { Qualitative measurement; } \\
\mathrm{CH}_{4} \text { and } \mathrm{CO}_{2}\left(\% \text { vol.), } \mathrm{H}_{2} \mathrm{~S}(\mathrm{ppm}) ;\right. \\
\text { MULTITEC } 540 \text { gauge (Sewerin) }\end{array}$ & - & - \\
\hline
\end{tabular}

\subsection{Experimental Design and Operating Conditions}

\subsubsection{Ultrasonic Disintegration}

Two different experimental ultrasonic devices were applied for WAS ultrasonic disintegration. The first device (A) consists of disintegrator of high power disintegrator WK-2010, equipped with "sandwich" head and "lens" emitter (designed and manufactured by SemiInstruments, Zabrze, Poland). This device is also equipped with a gauge allowing to read the frequency, as wells as with a steel chamber where the UD of sludge samples takes place. The second device (B) consists of ultrasonic washer which is a rectangular chamber, equipped with a single "flat" emitter of "sandwich" type placed in the bottom of the chamber (designed and manufactured by ZUT Intersonic S.C., Olsztyn, Poland). The technical characteristics and operating conditions of the experimental devices are shown in Table 3.

Table 3. Technical characteristics and operating conditions of the experimental ultrasonic devices.

\begin{tabular}{ccccc}
\hline Parameter & Symbol & Unit & WK-2010 & Ultrasonic Washer \\
\hline Power & $\mathrm{P}$ & $\mathrm{W}$ & 650 & 90 \\
Frequency & $\mathrm{f}$ & $\mathrm{kHz}$ & 25 & 25 \\
Number of emitters & - & - & 1 & 1 \\
Emitter surface area & $\mathrm{A}_{\mathrm{E}}$ & $\mathrm{cm}^{2}$ & 78.5 & 19.6 \\
Emitter diameter & $\mathrm{d}_{\mathrm{E}}$ & $\mathrm{cm}$ & 10 & 5 \\
Emitter position & $\mathrm{h}_{\mathrm{E}}$ & $\mathrm{cm}$ & $1{ }^{1}$ & built \\
Chamber dimensions & $\mathrm{idc} \times \mathrm{dc}$ & $\mathrm{cm}$ & $14 \times 7^{2}$ & $15 \times 13.7 \times 20^{3}$ \\
Chamber volume & $\mathrm{V}_{\mathrm{C}}$ & $\mathrm{mL}$ & 1000 & 2000
\end{tabular}

1 emitter position relative to the sludge mirror; ${ }^{2}$ dimension of chamber for sludge UD (ultrasonic disintegration) in relation to WK-2010 (internal diameter, depth); ${ }^{3}$ internal dimensions of the ultrasonic washer (front, side, depth).

The WAS samples pretreatment were performed under a constant energy supply (over time) per sludge volume, i.e., $\mathrm{E}_{\mathrm{V}}=160 \mathrm{kWh} \cdot \mathrm{m}^{-3}\left(\mathrm{E}_{\mathrm{S}}\right.$-in the range of $10,868-23,226 \mathrm{~kJ} \cdot \mathrm{kg}^{-1} \mathrm{TS}$; app. 
$15,111 \mathrm{~kJ} \cdot \mathrm{kg}^{-1} \mathrm{TS}$ ). Sludge samples were disintegrated for: $267 \mathrm{~s}$ (WK-2010) and $1920 \mathrm{~s}$ (ultrasonic washer). The sample volume was constant and equal $\mathrm{V}=0.3 \mathrm{~L}$. The ultrasonic density $\left(\mathrm{U}_{\mathrm{D}}\right)$ for each of experimental device was as follows: $2.2 \mathrm{~W} \cdot \mathrm{cm}^{-3}(\mathrm{WK}-2010)$ and $0.3 \mathrm{~W} \cdot \mathrm{cm}^{-3}$ (ultrasonic washer). Whereas, the ultrasonic intensity $\left(\mathrm{U}_{\mathrm{I}}\right)$ was: $2.6 \mathrm{~W} \cdot \mathrm{cm}^{-2}(\mathrm{WK}-2010)$ and $1.9 \mathrm{~W} \cdot \mathrm{cm}^{-2}$, respectively. The above conditions were the most favorable ones and were determined in the course of previously carried out studies. The variable parameter during sludge UD was the amount of specific energy $\left(\mathrm{E}_{\mathrm{S}}\right)$, which depends on TS content. The values characterizing the ultrasound field and the amount of energy supplied to the process were calculated by the following Equations (1)-(4):

$$
\begin{gathered}
E_{V}=\frac{P \times t}{V} \\
E_{S}=\frac{P \times t}{V \times T S} \\
U_{D}=\frac{P}{V} \\
U_{I}=\frac{P}{A_{E}}
\end{gathered}
$$

where: $\mathrm{E}_{\mathrm{V}}$ - energy supplied per sludge volume $\left(\mathrm{kWh} \cdot \mathrm{m}^{-3}\right)[16] ; \mathrm{E}_{\mathrm{S}}$ - specific energy $\left(\mathrm{kJ} \cdot \mathrm{kg}_{\mathrm{TS}}{ }^{-1}\right)$ [17]; $\mathrm{U}_{\mathrm{D}}$-ultrasonic density $\left(\mathrm{W} \cdot \mathrm{cm}^{-3}\right)$ [36]; $\mathrm{U}_{\mathrm{I}}$-ultrasonic intensity $\left(\mathrm{W} \cdot \mathrm{cm}^{-2}\right)$ [16]; P-power of the ultrasonic generator $(\mathrm{W} ; \mathrm{kW}) ; \mathrm{V}$-volume of a sludge sample $\left(\mathrm{m}^{3} \cdot \mathrm{cm}^{3}\right) ; \mathrm{t}$-sonication time $(\mathrm{s}) ; \mathrm{TS}$ - total solids; $\left(\mathrm{g} \cdot \mathrm{L}^{-1}\right) ; \mathrm{A}_{\mathrm{E}}$ - surface area of the disintegration $\left(\mathrm{cm}^{2}\right)$.

\subsubsection{Anaerobic Digestion}

The anaerobic digestion was conducted in the installation consisting of the anaerobic glass digesters with a working volume of $0.5 \mathrm{~L}$, water bath-in order to maintain a constant temperature, columns to collect and measure the volume of evolved biogas and MULTITEC 540 gauge (Sewerin, Warszawa, Poland)—applied for composition analysis. AD was conducted under mesophilic conditions $\left(37^{\circ} \mathrm{C} \pm 0.5^{\circ} \mathrm{C}\right)$ over 20 days, each time. The examined sample was a mixture of: digested sludge $(30 \%)$ collected from the fermentation chamber of the Central WWTP in Gliwice and ultrasonically pretreated one (70\%) from the same WWTP. Control sample constituted mixture of untreated and digested sludge. During the AD process each digester was shaken manually three times per day to prevent the sludge from settling. The process was conducted once a month (for a period of 7 months). The research position was made by Wytwórnia Przyrządów Laboratoryjnych (WPL) Gliwice, according to DIN 38414-8:1985 [37].

\subsection{Direct and Technological Effects}

In order to determine the direct and technological effects of sludge UD process, selected indicators were used (defined in Section 2.3.1). The assessment of the direct effects included changes of: $\mathrm{pH}$ value, concentration of SCOD, $\mathrm{P}_{\mathrm{TOT}}, \mathrm{N}_{\mathrm{TOT}}$, proteins and carbohydrates, as well as CST measurement and sludge flocs optical microscopy analysis. Whereas, the technological effects observed after completion of sludge $\mathrm{AD}$ included the same parameters as for the direct once (except SCOD, extracellular polymeric substances (EPS) and microscopic analysis). Moreover, process of AD was also controlled by the volume and composition of the evolved biogas, as well as by measuring the rate of TS and VS reduction.

\subsubsection{Indicators of the Direct and Technological Effects}

In order to evaluate the direct and technological effects of WAS ultrasonic disintegration, a comprehensive analysis of the obtained results was conducted. The disintegration degree $\left(\mathrm{DD}_{\mathrm{COD}}\right)$ was determined using indicator proposed by Müller [14] (Equation (4). Whereas, the magnitude of the obtained effects was assessed using author's indicators $\left(\mathrm{ID}_{\mathrm{i}}, \mathrm{IT}_{\mathrm{i}}, \mathrm{IT}_{\mathrm{d}}\right)$ based on the ratio of the 
concentration or value of specific compound resulting from changes in the sludge characteristics, as a result of its pretreatment [13] (Equations (5) and (7)):

$$
\mathrm{DD}_{\mathrm{COD}}=\frac{\mathrm{SCOD}_{\mathrm{UD}}-\mathrm{SCOD}_{0}}{\mathrm{SCOD}_{\mathrm{NaOH}}-\mathrm{SCOD}_{0}} \times 100
$$

where: $\mathrm{DD}_{\mathrm{COD}}$-disintegration degree of $(\%), \mathrm{SCOD}_{0}$ and $\mathrm{SCOD}_{\mathrm{UD}}$ - supernatant $\mathrm{COD}$ of the original and disintegrated sample $\left(\mathrm{mg} \cdot \mathrm{L}^{-1}\right), \mathrm{SCOD}_{\mathrm{NaOH}}$ - the maximum $\mathrm{COD}_{\mathrm{NaOH}}$ obtained by alkaline hydrolysis $\left(0.5 \mathrm{M} \mathrm{NaOH}\right.$, ratio of $1: 1$ for 22 hours at $\left.20^{\circ} \mathrm{C}\right)\left(\mathrm{mg} \cdot \mathrm{L}^{-1}\right)$.

$$
\begin{gathered}
\text { IDi; ITi }=\frac{C_{U D}}{C_{N U D}} \\
\text { IDd;ITd }=\frac{C_{N U D}}{C_{U D}}
\end{gathered}
$$

where: IDi-direct effects indicator relating to the increase of concentration or value of specific compound in sludge/supernatant, in the process of UD; ITi-technological effects indicator relating to the increase of concentration or value of specific compound in sludge/supernatant, in the process of $\mathrm{UD}$, observed after AD; IDd-direct effects indicator relating to the decrease of concentration or value of specific compound in sludge/supernatant, in the process of UD; ITd-technological effects indicator relating to the decrease of concentration or value of specific compound in sludge/supernatant, in the process of UD, observed after $A D ; C_{N U D}$ and $C_{U D}$ - concentration or value of a specific compound in the sludge/supernatant of non-disintegrated and disintegrated sludge, respectively $\left(\mathrm{mg} \cdot \mathrm{L}^{-1}\right),(\mathrm{s})$.

\subsection{Statistical Analysis}

In order to evaluate the obtained results, a comprehensive statistical analysis was conducted. The calculations were performed with Statistica 12.0 (StatSoft) and Excel 2013 (Microsoft Office Standard). To check the differences in the mean concentrations of specific compounds between related groups of variables (sludge characteristics before and after UD and AD processes), $T$-Test was used. The occurrence of a linear correlation between analyzed variables was evaluated by Pearson's correlation coefficient (r). To determine whether any of the differences between the means are statistically significant, one-way analysis of variance (ANOVA) was used. Tests were carried out with a confidence level of $95 \%$.

\section{Results and Discussion}

\subsection{Direct Effects}

The characteristics of WAS before and after ultrasonic pretreatment are shown in Table 4 . The values of parameters analyzed in WAS (collected periodically for 7 months), were in the range of: 6.9-7.2 (pH); 24.8-53.2 g. $\mathrm{L}^{-1}$ (TS); 24.8-53.2 g. $\mathrm{L}^{-1}$ (VS); 46.6-82.7 $\mathrm{mg} \cdot \mathrm{L}^{-1}$ (SCOD); 8.2-12.4 $\mathrm{mg} \cdot \mathrm{L}^{-1}$ ( $\mathrm{N}_{\mathrm{TOT}}$ ), $16.2-37.7 \mathrm{mg} \cdot \mathrm{L}^{-1}$ ( $\mathrm{P}_{\mathrm{TOT}}$ ); 624.6-1228.2 $\mathrm{mg} \cdot \mathrm{L}^{-1}$ (proteins); $241.7-821.7 \mathrm{mg} \cdot \mathrm{L}^{-1}$ (carbohydrates) and $7-13 \mathrm{~s}$ (CST). Among all examined parameters, the $\mathrm{pH}$ was characterized by the lowest variability $(\mathrm{CV}=2.0 \%)$, whilst the concentration of carbohydrates by the highest one $(\mathrm{CV}=35.6 \%)$.

As a result of WAS pretreatment, the $\mathrm{pH}$ value slightly decreased and was in the range from 6.7 to 7.2 and 6.5 to 7.1, for sludge disintegrated in the WK-2010 (WAS_A) and ultrasonic washer (WAS_B), respectively. The highest variability was observed for sludge pretreated in the ultrasonic washer (CV $=2.7 \%$ ). The decrease of $\mathrm{pH}$ was also confirmed by $\mathrm{IDd}_{\mathrm{pH}}$, which values were lower than 1.0 (for this reason, it was not included in Figure A1). The above observations were in good agreement with author's previous research [13]. The influence of ultrasonic pretreatment on decreasing of $\mathrm{pH}$ value, was also confirmed by other scientist [38], who claimed that it is probably posed by formation of acidic compound resulted from flocs disintegration. Whereas, other researches indicated that ultrasonic 
pretreatment did not change the $\mathrm{pH}$ of sludge [39]. It was also suggested that for effective sludge ultrasonic disintegration, the value of $\mathrm{pH}$ must be adjusted to a suitable level $[15,40]$.

Table 4. The characteristics of the WAS before and after ultrasonic pretreatment-direct effects $(n=7)$.

\begin{tabular}{ccccc}
\hline \multirow{2}{*}{ Parameter } & Unit & WAS_NUD & WAS_A & WAS_B \\
\cline { 3 - 5 } & & & Mean; CV \\
pH & - & $7.0(2.0 \%)$ & $6.9(2.2 \%)$ & $6.8(2.7 \%)$ \\
$\mathrm{TS}$ & $\mathrm{g} \cdot \mathrm{L}^{-1}$ & $41.1(26.9 \%)$ & - & - \\
$\mathrm{VS}$ & $\mathrm{g} \cdot \mathrm{L}^{-1}$ & $29.8(29.2 \%)$ & - & - \\
$\mathrm{SCOD}_{0} / \mathrm{SCOD}$ & $\mathrm{mg} \cdot \mathrm{L}^{-1}$ & $66.8(22.8 \%)$ & $1061.7(34.8 \%)$ & $4573.4(39.2 \%)$ \\
$\mathrm{N}_{\mathrm{TOT}}$ & $\mathrm{mg} \cdot \mathrm{L}^{-1}$ & $10.9(16.3 \%)$ & $139.9(23.8 \%)$ & $470.4(37.5 \%)$ \\
$\mathrm{P}_{\text {TOT }}{ }^{-1}$ & $\mathrm{mg} \cdot \mathrm{L}^{-1}$ & $25.1(31.4 \%)$ & $135.6(22.5 \%)$ & $177.0(18.7 \%)$ \\
Proteins & $\mathrm{mg} \cdot \mathrm{L}^{-1}$ & $888.9(24.9 \%)$ & $784.0(35.1 \%)$ & $927.5(29.2 \%)$ \\
Carbohydrates & $\mathrm{mg} \cdot \mathrm{L}^{-1}$ & $598.4(35.6 \%)$ & $480.7(47.5 \%)$ & $507.0(46.9 \%)$ \\
CST & $\mathrm{S}$ & $9.0(24.8 \%)$ & $343.1(70.0 \%)$ & $1175.1(10.2 \%)$ \\
$\Delta \mathrm{T}$ & ${ }^{\circ} \mathrm{C}$ & - & $14.0(39.7 \%)$ & $34.0(29.5 \%)$ \\
\hline
\end{tabular}

WAS_NUD—WAS before pretreatment; WAS_A-WAS after pretreatment in the WK-2010; WAS_B-WAS after pretreatment in the ultrasonic washer; CV-coefficient of variation; TS-total solids; VS-volatile solids; $\mathrm{SCOD}_{0}-\mathrm{SCOD}$ of the supernatant of the original sludge; $\mathrm{SCOD}_{\mathrm{UD}}-\mathrm{SCOD}$ value of the supernatant of the disintegrated sludge; TN—total nitrogen; TP-total phosphorus; CST-capillary suction time; $\Delta \mathrm{T}$-temperature increase.

The concentrations of SCOD in the supernatant after sludge pretreatment, were in the range of $741.0-1827.0 \mathrm{mg} \cdot \mathrm{L}^{-1}$ (WAS_A) and $1842.0-6935.0 \mathrm{mg} \cdot \mathrm{L}^{-1}$ (WAS_B). Higher variability of examined parameter was observed for sludge undergone disintegration in the ultrasonic washer $(\mathrm{CV}=39.2 \%)$. The biggest increase of SCOD concentration in the sludge supernatant was noted in July and September, when the TS content was in the range of $24.8-35.5 \mathrm{~g} \cdot \mathrm{L}^{-1}$. The above observations were confirmed by $\mathrm{DD}_{\mathrm{COD}}$ and IDisCOD, which maximum values amounted: 37.5 and $91.7 \%$ (Figure 1), as well as 24.1; 113.0 (Figure A1) for WAS pretreated in WK-2010 and ultrasonic washer, respectively. The influence of TS content on SCOD release was also confirmed by the other researchers, who claimed that its optimal value should be in the range of $2.0-3.2 \%$ [11,41]. However, there have been many studies reporting an increase of SCOD concentration in the supernatant after sludge ultrasonic pretreatment. For example, it was indicated that after $40 \mathrm{~min}$ of sludge pretreatment conducted at $\mathrm{E}_{\mathrm{S}}=9690 \mathrm{~kJ} \cdot \mathrm{kg}^{-1} \mathrm{TS}$, $\mathrm{DD}_{\mathrm{COD}}$ reached 57.9\% [18]. Moreover, other researchers indicated that the SCOD solubilisation and disintegration degree may depend on the amount of energy input, sonication time or frequency of ultrasonic wave $[3,10,16]$. However, there is one more important factor, which affects the release of SCOD into supernatant, i.e., the increase of sludge temperature. The conducted experiment showed, that depending on the type of device used for sludge sonication, the increase of sludge temperature ranged from 8 to $22{ }^{\circ} \mathrm{C}$ (WK-2010) and 32 to $37^{\circ} \mathrm{C}$ (ultrasonic washer). Furthermore, the highest values of $\Delta \mathrm{T}$ were observed at the lowest TS content and amounted: 22 and $37^{\circ} \mathrm{C}$, respectively (Figure 2). The above observations were confirmed by other researcher, who indicated that at a constant energy input $\left(E_{\mathrm{V}}=100 \mathrm{kWh} \cdot \mathrm{m}^{-3}\right)$, higher increase of sludge temperature was obtained at lower TS content, i.e., from 27.2 to $38.2{ }^{\circ} \mathrm{C}$ at TS $=2.0 \%$ and 18.0 to $29.0^{\circ} \mathrm{C}$ at TS $=4.2 \%$ [23]. Moreover, the results of another research revealed, that the increase of sludge temperature may increase linearly with increasing value of specific energy input to the process, i.e., temperature of sludge increased from $22{ }^{\circ} \mathrm{C}$ in original sample to $72{ }^{\circ} \mathrm{C}$ for disintegrated one, at a maximum $\mathrm{E}_{\mathrm{S}}=15,880 \mathrm{~kJ} \cdot \mathrm{kg}^{-1} \mathrm{TS}$ [18]. It is important to note that, the increase of WAS temperature during ultrasonic pretreatment generally has a positive influence on sludge solubilisation, but to avoid of any undesirable effects relating, e.g., with recycling back of leachate (generated after sludge pretreatment) to the biological process, it must be undergo testing and further controlled. 


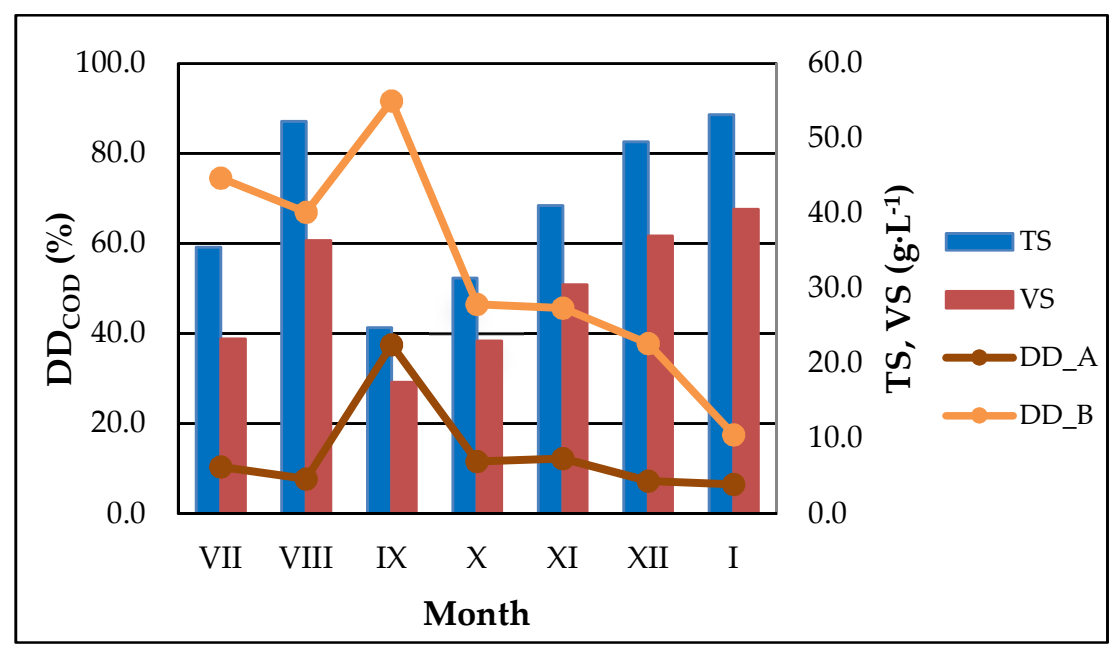

Figure 1. Evolution of disintegration degree (DD $\mathrm{DOD}_{\mathrm{CO}}$ ) vs total solids (TS) and volatile solids (VS) content of waste activated sludge (WAS).

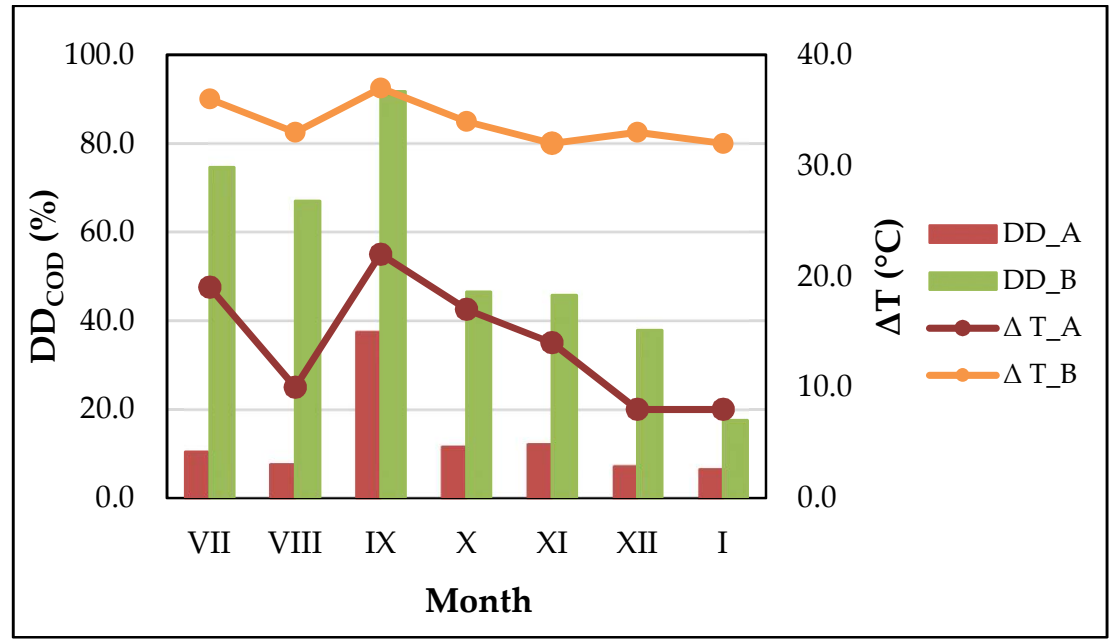

Figure 2. Evolution of disintegration degree $\left(\mathrm{DD}_{\mathrm{COD}}\right)$ vs temperature increase $(\Delta \mathrm{T})$ of waste activated sludge (WAS).

This study revealed that ultrasonic pretreatment of WAS increased the concentration of biogenic substances in the sludge supernatant. The concentration of total nitrogen ranged from 99.5 to $196.0 \mathrm{mg} \cdot \mathrm{L}^{-1}$ (WAS_A) and 210.0 to $719.0 \mathrm{mg} \cdot \mathrm{L}^{-1}$ (WAS_B), while for the total phosphorus from 91.5 to $187.0 \mathrm{mg} \cdot \mathrm{L}^{-1}$ and 126.0 to $223.0 \mathrm{mg} \cdot \mathrm{L}^{-1}$, respectively. The concentration of $\mathrm{N}_{\mathrm{TOT}}$ was characterized by higher variability during the experiment duration. The value of $\mathrm{CV}$ for $\mathrm{N}_{\mathrm{TOT}}$ and $\mathrm{P}_{\mathrm{TOT}}$ were in the range of $23.8-37.5 \%$ and $18.7-22.5 \%$, respectively. Almost for all examined sludge samples, the

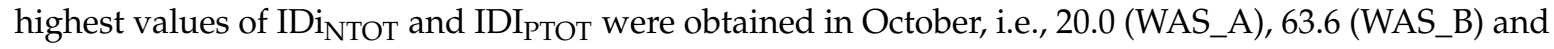
8.7 (WAS_A); 11.4 (WAS_B) respectively (Figure A1), while the lowest in January. The above effects were probably additionally strengthened by the increase of temperature during sludge ultrasonic pretreatment. The obtained results are in good agreement with author's earlier research [13]. Moreover, in the scientific papers little attention is given to the release of biogenic substances in the supernatant during the ultrasonic pretreatment of sludge. However, some of the conducted research indicated that increase of specific energy increased the concentration of total nitrogen and phosphorus by $716 \%$ and $207.5 \%$, respectively (at $\mathrm{E}_{\mathrm{S}}=9690 \mathrm{~kJ} \cdot \mathrm{kg}^{-1} \mathrm{TS}$ ) [18]. It is important to note that most part of nitrogen and phosphorus in the sludge supernatant existed in the form of organic products. Thus, the increase of biogenic substances concentration in the supernatant after sludge pretreatment may be associated 
with the concentration of SCOD or extracellular polymeric substances $[17,18]$. The above finding was confirmed in this work.

As a result of ultrasonic disintegration of WAS, for most of the analyzed sludge samples the decrease in proteins concentration were observed. The only exception was shown for the sludge samples pretreated in ultrasonic washer, where the increase of proteins content was observed (except of September and November, when TS content was the lowest and $\Delta \mathrm{T}$ almost the highest). The proteins concentration in the supernatant fluctuated in the range from: 465.3 to $1213.5 \mathrm{mg} \cdot \mathrm{L}^{-1}$ (WAS_A) and 618.5 to $1310.9 \mathrm{mg} \cdot \mathrm{L}^{-1}$ (WAS_B). The above results were confirmed by the values of IDiPROT. and

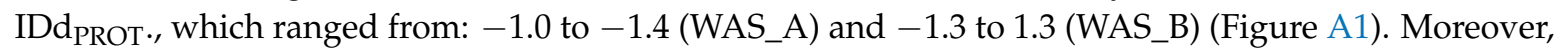
similar observations were made for carbohydrates, where their concentration in the supernatant was in the range of: $108.3-754.2 \mathrm{mg} \cdot \mathrm{L}^{-1}$ (WAS_A) and $115.0-790.0 \mathrm{mg} \cdot \mathrm{L}^{-1}$ (WAS_B). The values of IDd amounted: -1.1 to -2.2 (WAS_A) and -1.0 to -2.1 (WAS_B) (Figure A1). The highest variability of above extracellular polymeric substances was observed for sludge samples disintegrated in the WK-2010, i.e., $C V=35.1 \%$ and CV $=47.5 \%$, for proteins and carbohydrates, respectively. Moreover, sum of EPS, during whole time of experiments duration were decreased. The obtained results were in the good agreement with those obtained by other researchers. For example, it was claimed that the increase of EPS concentration in the supernatant after sludge ultrasonic pretreatment (ES in the range of $0.1-50 \mathrm{~kJ} \cdot \mathrm{kg}^{-1} \mathrm{TS}$ ) increased the concentration of above substances initially, but with increasing energy supplied to the process their content decreased [19]. Whereas, other researchers indicated that ultrasonic pretreatment of WAS, conducted at high level of specific energy (up to $26,000 \mathrm{~kJ} \cdot \mathrm{kg}^{-1} \mathrm{TS}$ ) increased the concentration of EPS in the sludge supernatant [17]. However, it must be emphasized, that in the above mentioned study, sludge temperature raised only by $4{ }^{\circ} \mathrm{C}$. It is important to note that proteins and carbohydrates constitute one of the most important components of EPS (they are part of sludge flocs). Thus, its presence in sludge play a significant role in regulating sludge dehydration ability [42], which was confirmed in this work. For example, some researchers indicated that sludge dewaterability may initially increase with the increase of EPS and then decreased when EPS content exceeded a certain threshold [43].

Ultrasonic pretreatment of WAS caused deterioration of the sludge dewaterability expressed by the increase of CST value, which ranged from 147 to 627 (A) and 1042 to 1396 (B). The highest values of CST were noted in September, while the lowest in January, when the TS content was $24.8 \mathrm{~g} \cdot \mathrm{L}^{-1}$ and $53.2 \mathrm{~g} \cdot \mathrm{L}^{-1}$, respectively. The values of IDi ${ }_{\text {CST }}$ were in the range of 6.2-102.6 (WAS_A) and 78.2-199.4 (WAS_B) (Figure A1). Similar observations were made by other researcher, who claimed, that at constant energy input to the process of sludge ultrasonic pretreatment, higher values of CST were obtained at lower TS content [11]. Other scientists indicated that CST may increase with an increase of specific energy input to the process [7]. Moreover, generally it was revealed that CST $=20 \mathrm{~s}$ is regarded as representative for a good dewatered sludge [44]. In this study, deterioration of sludge dewaterability was probably caused by the fragmentation of solid fraction and weakens the internal structure, which resulted in the increase of sludge surface characterized with very small particles. Deterioration of the sludge dehydration could also be associated with the release of EPS during sludge pretreatment [42].

In order to compare the changes in flocs structure, occurring as a result of WAS pretreatment, three samples were selected and subjected to microscopic examination. They differed in TS content. The first one (S1) was characterized by a lowest TS $\left(24.8 \mathrm{~g} \cdot \mathrm{L}^{-1}\right)$; second one (S2) by mean $\left(35.5 \mathrm{~g} \cdot \mathrm{L}^{-1}\right)$ and third one by a highest TS content $\left(53.2 \mathrm{~g} \cdot \mathrm{L}^{-1}\right)$, among of all samples analyzed during seven months of the experiment conducting. The collection of above samples was conducted in: September, July and January, respectively. The results were presented depending on the type of disintegrator used for sludge pretreatment, i.e., WK-2010 (A1-A3) and ultrasonic washer (B1-B3) (Figure 3). The optical microscopy analysis indicated significant differences in the flocs structure before and after sludge pretreatment. The most visible changes were observed for WAS disintegrated in the ultrasonic washer. A strong breakdown and dispersion of the flocs were observed. The experiment showed, that both sludge characteristics and technical conditions of process conducting, have a considerable impact on 
the sludge structure. The above observations were confirmed in author's previous studies $[13,24]$. Moreover, the usefulness of microscopic analysis in assessing the direct effects of sludge ultrasonic disintegration, has also been demonstrated by other researchers [5,17].

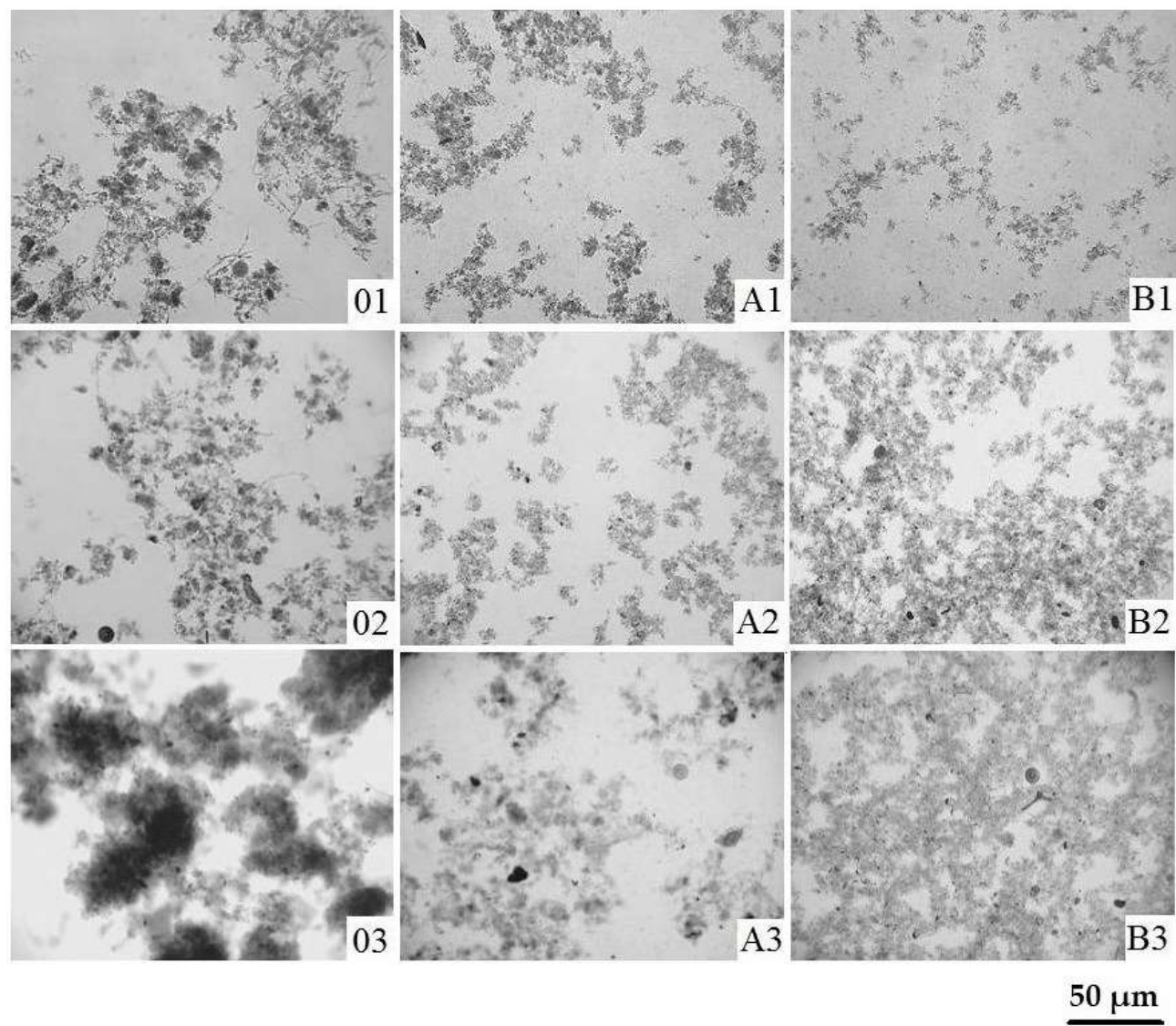

Figure 3. Photomicrographs of the: non-disintegrated (01-03) and disintegrated WAS (A-WK-2010; B-ultrasonic washer) at different total solids (TS) content: $24.8 ; 35.5$ and $53.2 \mathrm{~g} \cdot \mathrm{L}^{-1}$, respectively (100× magnification).

\subsection{Technological Effects}

The characteristics of inoculum, as well as samples containing untreated or disintegrated WAS (mixed with inoculum), before (S_0; S_A; S_B, respectively) and after the process of AD (S_0*; S_A*; S_B ${ }^{*}$, respectively) are shown in Table 5 .

It was indicated that mixtures containing WAS after ultrasonic pretreatment (S_A; S_B), were characterized by higher concentrations and values of examined parameters, compared to the control sample (S_0). The highest variability in the mixtures before AD was expressed by $\mathrm{P}_{\mathrm{TOT}}$ concentration and CST values. Similar relations were observed in with reference to mixtures after AD process. For both samples, before and after $\mathrm{AD}$, the lowest variability was observed for $\mathrm{pH}$ value.

The conducted experiment indicated, that after AD process, following changes in the examined mixtures were observed: the increase of $\mathrm{pH}, \mathrm{N}_{\mathrm{TOT}}$ and $\mathrm{P}_{\mathrm{TOT}}$ concentration, as well as the reduction of TS and VS content and increase of biogas production. While, CST values were generally decrease. The above observations were confirmed by ITi and ITd (Figure A2). Moreover, due to the low values of $\operatorname{Iti}_{\mathrm{pH}}(<1.0)$, this parameter was not included in Figure A2. 
Table 5. The characteristics of the sludge sample before and after anaerobic digestion-technological effects.

\begin{tabular}{|c|c|c|c|c|c|c|c|c|}
\hline \multirow{2}{*}{ Parameter } & \multirow{2}{*}{ Unit } & Inoculum & S_0 & S_0* & S_A & S_A* & S_B & S_B* \\
\hline & & \multicolumn{7}{|c|}{ Mean; CV (\%) } \\
\hline $\mathrm{pH}$ & - & $7.4 \pm(1.7 \%)$ & $7.5(1.4 \%)$ & $7.5(1.1 \%)$ & $7.3(1.7 \%)$ & $7.6(1.2 \%)$ & $7.3(1.6 \%)$ & $7.6(1.3 \%)$ \\
\hline TS & $\mathrm{g} \cdot \mathrm{L}^{-1}$ & $26.2(15.1 \%)$ & $36.8(19.8)$ & $30.2(21.3 \%)$ & $37.5(19.0 \%)$ & $29.2(20.6 \%)$ & $38.7(17.9 \%)$ & $28.6(19.4 \%)$ \\
\hline VS & $\mathrm{g} \cdot \mathrm{L}^{-1}$ & $15.9(14.3 \%)$ & $25.2(20.2 \%)$ & $18.7 .1(21.6 \%)$ & $26.7(20.5 \%)$ & $18.2(21.8 \%)$ & $27.4(18.8 \%)$ & $17.7(20.3 \%)$ \\
\hline $\mathrm{N}_{\mathrm{TOT}}$ & $\mathrm{mg} \cdot \mathrm{L}^{-1}$ & $728.1(11.3 \%)$ & $210.6(7.1 \%)$ & $925.6(18.5 \%)$ & $277.0(7.5 \%)$ & $951.8(19.4)$ & $436.6(21.9 \%)$ & $1064.6(16.8 \%)$ \\
\hline $\mathrm{P}_{\mathrm{TOT}}$ & $\mathrm{mg} \cdot \mathrm{L}^{-1}$ & $116(44.5 \%)$ & $68.7(52.6)$ & $288.6(54.7 \%)$ & $130.4(37 \%)$ & $270.1(60.3 \%)$ & $145.8(35.7 \%)$ & $258.8(64.1 \%)$ \\
\hline CST & s & $186.4(26.6 \%)$ & $42.6(30.6 \%)$ & $78.6(63.8 \%)$ & $352.4(55.9 \%)$ & $215.3(43.8 \%)$ & $1068.3(10.7 \%)$ & 342.7 (42.2\%) \\
\hline $\begin{array}{l}\text { Total biogas } \\
\text { production }\end{array}$ & $\mathrm{cm}^{3}$ & - & - & $2014.0(32.4 \%)$ & - & $2276.0(34.0 \%)$ & - & $2411.0(29.0 \%)$ \\
\hline $\mathrm{CH}_{4}$ & \%vol. & - & - & $65.6(5.7 \%)$ & - & $66.0(5.1 \%)$ & - & $67.9(4.6 \%)$ \\
\hline $\mathrm{CO}_{2}$ & \%vol. & - & - & $25.9(16.6 \%)$ & - & $25.6(15.8 \%)$ & - & $25.9(12.1 \%)$ \\
\hline $\mathrm{H}_{2} \mathrm{~S}$ & ppm & - & - & $<1.0$ & - & $<1.0$ & - & $<1.0$ \\
\hline
\end{tabular}

S_0—-sample before AD containing inoculum and original sludge; S_0*-sample after AD containing inoculum and original sludge; S_A—sample before AD containing inoculum and WAS_A; S_A*-sample after AD containing inoculum and WAS_A; S_B — sample before AD containing inoculum and WAS_B; S_B TS-total solids; VS-volatile solids; $\mathrm{N}_{\mathrm{TOT}}$ - total nitrogen; $\mathrm{P}_{\mathrm{TOT}}$ - total phosphorus; $\mathrm{CST}$-capillary suction time; methane $\left(\mathrm{CH}_{4}\right)$, carbon dioxide $\left(\mathrm{CO}_{2}\right)$ and hydrogen sulfide $\left(\mathrm{H}_{2} \mathrm{~S}\right)$ content in evolved biogas; vol.-volume. 
As a result of ultrasonic disintegration of WAS, in the mixture derived from anaerobic digestion process a high increase of $\mathrm{N}_{\mathrm{TOT}}$ and $\mathrm{P}_{\mathrm{TOT}}$ concentration, were observed. The values of $\mathrm{ITi}_{\mathrm{NTOT}}$ and ITi respectively (Figure A2). The lowest increase of above mentioned parameters was observed for the mixtures containing sludge after pretreatment in the ultrasonic washer, for which the temperature increase was the highest. It was also indicated, that the increase of biogenic substances in sludge supernatant after AD process was higher in the control sample. The above observations were confirmed by author's previous work, in which ITi $\mathrm{NTOT}_{\mathrm{N}}$ values for the reference samples were in the range of 3.2-5.7 and for mixtures containing disintegrated sludge equaled 2.4-5.5. While in respect to ITiP $\mathrm{P}_{\mathrm{TOT}}$, those values were from 3.5 to 4.9 and 1.5 to 2.8, respectively [13]. Moreover, the increase of biogenic substances in the supernatant after anaerobic digestion of WAS, was associated with the increase of TS and VS content, as well as the decrease of CST value in the samples before the process, which resulted from characteristics of sludge undergone ultrasonic disintegration. Furthermore, the changes in the concentration of total nitrogen in the supernatant after and before sludge AD, were correlated with the increase of biogas production. Whereas, in the case of the total phosphorus, changes in the concentration of this compound, were related with the amount of evolved biogas. The increase in concentration of biogenic substances in the supernatant after sludge $\mathrm{AD}$, was also observed by other researchers [45]. Moreover, these findings can be positive with respect to necessity of recycling the leachate generated after dehydration of digested sludge into the technological line of WWTP.

The reduction of TS and VS content in the samples containing sludge after UD was in the ranged of: $17.8-26.8 \%$; $22.6-29.6 \%$ and $29.5-35.6 \%$; $33.1-38.0 \%$, for S_A ${ }^{*}$; S_B*, respectively. It was showed that the obtained TS and VS reduction was higher in comparison to the control sample by: $4.1 ; 8.0 \%$ and 5.8 ; $9.5 \%$, for S_A $A^{*}$ S_B $B^{*}$; respectively (Figure 4 ). The highest decrease of TS and VS content was observed for samples containing WAS after pretreatment in the ultrasonic washer, compared to the control sample. Moreover, the reduction of TS and VS content increased the biogas production. The above results were in good agreement with other researchers, who stated, that ultrasonic pretreatment of sludge, increased VS reduction and biogas production by: $19 \%$ and $26 \%$, respectively [46]. Whereas, the results of other investigation, indicated that ultrasonic pretreatment of sludge prior anaerobic digestion, ensured: $12 \%$ increase of TS content, compared to the control sample [21].

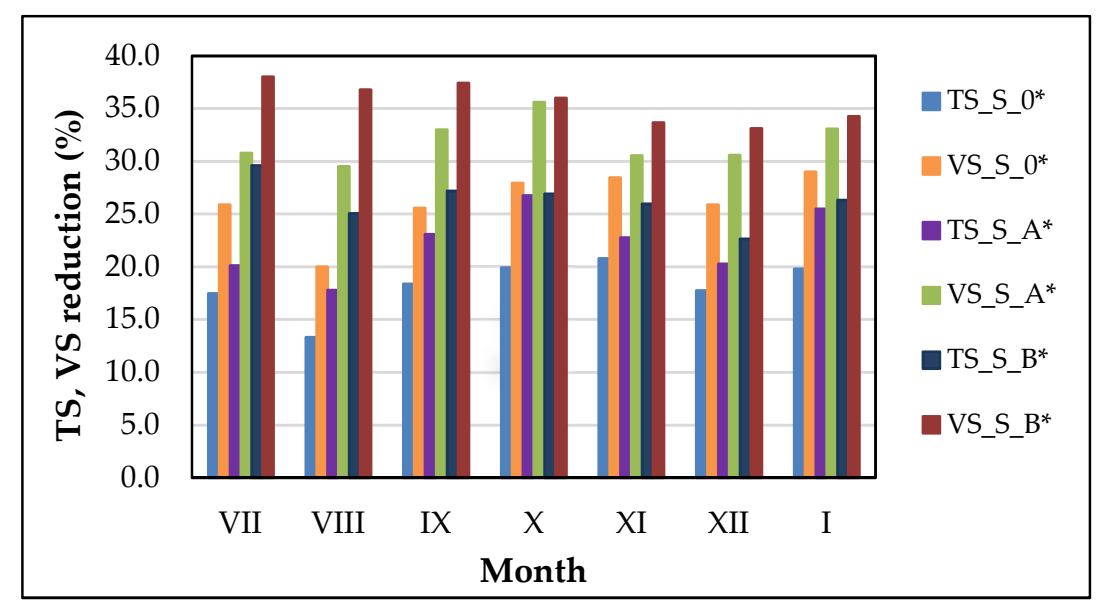

Figure 4. Total solids (TS) and volatile solids (VS) reduction after anaerobic digestion (AD) process.

The changes of CST values in the sludge mixtures after anaerobic digestion revealed, that the best effects of sludge dehydration were obtained for samples containing WAS, after pretreatment in the ultrasonic washer. The values of ITi $_{\mathrm{CST}}$ and ITd $\mathrm{CSST}_{\mathrm{C}}$ were in the range of: -1.3 to $2.8 ;-3.9$ to $2.4 ;-1.8$ to -7.6 , for $S \_0^{*}$; S_A* and S_B*, respectively (Figure A2). The best effects were obtained in the first, third and fourth month of experiments procurement. The obtained results are probably dependent on the characteristic of sludge samples after ultrasonic pretreatment, i.e., the worse susceptibility of 
sludge to dewatering (larger surface area of the flocks), the greater degree of sludge defragmentation, which favors the course of the anaerobic digestion process [8]. The above observations were in a good agreement with those obtained by other researchers, who achieved $49 \%$ reduction of CST after AD process of disintegrated sludge, compared to control sample [47]. Whereas, other scientists reported a 7-fold decrease of CST value (from $2000 \mathrm{~s}$ to $267 \mathrm{~s}$ ) in the examined sludge, in compare to reference sample [48].

The amount of total biogas production observed after the process of sludge anaerobic digestion is presented in Figure 5. Obtained results confirmed the positive effect of WAS ultrasonic pretreatment on the increase of biogas production. The higher volume of evolved biogas was obtained for a mixture containing disintegrated sludge, i.e., $13.0 \%\left(\mathrm{~S}_{-} \mathrm{A}^{*}\right)$ and $19.7 \%\left(\mathrm{~S} \_\mathrm{B}^{*}\right)$, in compare to control sample. The amount of biogas production did not undergoing a large variability during the experiment conducting, regardless of the technical conditions of WAS pretreatment, before AD process. The highest volume of evolved biogas was obtained from the mixture containing sludge after pretreatment in the ultrasonic washer $\left(2411 \mathrm{~cm}^{3}\right)$. The above observations were in a good agreement with the results obtained by other researchers. For example, it was stated that ultrasonic pretreatment of WAS at $20 \mathrm{kHz}$ and $\mathrm{P}=200 \mathrm{~W}$, increased biogas production by $6.3 \%$ [40]. Whereas, other scientists achieved of $8.6 \%$ to $31.4 \%$ improvement of biogas production, conducting ultrasonic disintegration, at specific energy, in the range of: 15,000 to $35,000 \mathrm{~kJ} \cdot \mathrm{kg}^{-1} \mathrm{TS}$ [10].

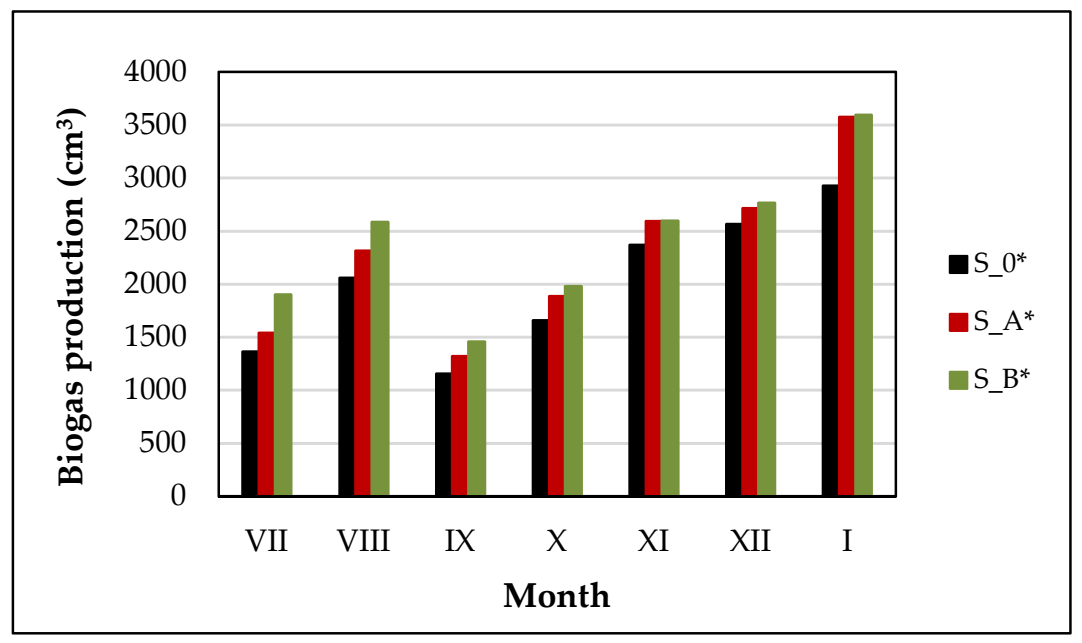

Figure 5. Biogas production after anaerobic digestion (AD) process.

This study revealed, that there were no significant differences between the qualities of biogas originating from the mixtures containing untreated and disintegrated WAS. The concentrations of $\mathrm{CH}_{4}, \mathrm{CO}_{2}$ and $\mathrm{H}_{2} \mathrm{~S}$ ranged from: 65.3 to $67.9 \%$ and 25.6 to $25.9 \%$, as well as $<1.0 \mathrm{ppm}$, respectively (Table 5). Similar composition of evolved biogas was indicated by other researchers, i.e., $\mathrm{CH}_{4}$ from 50 to $70 \% ; \mathrm{CO}_{2}$ from 25 to $30 \%$ and $\mathrm{H}_{2} \mathrm{~S}, \mathrm{H}_{2}, \mathrm{~N}_{2}<1 \%[49,50]$.

\subsection{Statistical Analysis}

In order to present the effects of ultrasonic disintegration as a function of WAS characteristics and technical conditions of the conducted process, a comprehensive analysis was carried out. In order to determine if there are any significant differences between examined variables, expressed as the changes in the characteristics of WAS before and after ultrasonic disintegration the T-Test was used. The strength of the relationship between periodical changes in the WAS characteristics (parameters) and obtained effects, was expressed as Pearson's correlation coefficient (r). Moreover, to indicate the differences between effects obtained in various technical conditions (disintegrators) of process conducting, the one-way analysis of variance (ANOVA) was carried out. 


\subsubsection{Analysis of Direct Effects}

The results of $T$-Test confirmed existence of significant differences in the characteristics of WAS before and after ultrasonic pretreatment $(p<0.05)$. The only exceptions were: $\mathrm{pH}$ for samples disintegrated in WK-2010, as well as proteins for ultrasonic washer $(p>0.05)$ (Table A1).

The results of Pearson's correlation are shown in Table A2 (WK-2010) and Table A3 (ultrasonic washer). A detailed analysis of correlation matrix revealed the existence of different relationships between the characteristics of sludge supernatant before and after WAS pretreatment. Moreover, apart from the statistically significant correlations, the ones for which " $r$ " was higher than 0.65 , were also taken into consideration. Taking into account the number of correlations between analyzed variables, it can be stated that the most important characteristics of WAS, which affects the magnitude of the direct effects, are: TS, VS, $\Delta \mathrm{T}>\mathrm{EPS}>\mathrm{SCOD}>\mathrm{CST}>\mathrm{N}_{\mathrm{TOT}}, \mathrm{P}_{\mathrm{TOT}}>\mathrm{pH}$. Moreover, data analysis also indicated that, the increase of sludge temperature during ultrasonic pretreatment of WAS exerted a significant impact on its final characteristics.

\subsubsection{Analysis of Technological Effects}

The $T$-Test results showed a significant differences in the characteristics of mixtures consisting of inoculum and pretreated WAS, prior and after anaerobic digestion $(p<0.05)$. The only exception was: CST for samples containing WAS after pretreatment in the ultrasonic washer $(p>0.05)$ (Table A4).

Furthermore, the results of Pearson's correlation revealed statistically significant differences between the characteristics of mixtures prior and after completion of anaerobic digestion (Tables A5 and A6). The above observations occurred regardless of the technical conditions of ultrasonic disintegration. In conclusion, it was found that the most important sludge parameters, which affect the magnitude of the technological effects, are: TS, VS $>$ CST $>\mathrm{N}_{\mathrm{TOT}}, \mathrm{P}_{\mathrm{TOT}}>\mathrm{pH}$. The sequence of above parameters was determined based on the number of correlations between analyzed variables. Moreover, taking into account VS reduction and increase of biogas production, it can be said that increase of sludge temperature during ultrasonic disintegration most likely causes the difference in its biodegradation.

\subsubsection{Analysis of Technological Conditions of Process Conducting}

The analysis of variance (ANOVA) showed that in the case of direct effects, there is a basis for rejecting the null hypothesis $(\mathrm{H} 0)$ on the about the absence of statistically significant differences between the variables in considered groups (except $\mathrm{pH}$, proteins and carbohydrates) (Table A7). It means, that above mentioned effects differ depending on the type of experimental device used in the process $(p<0.05)$. Whereas, the results of statistical analysis in accordance to technological effects indicated existence of significant differences between analyzed variables, but only in the case of changes in the CST values (Table A8). It means that technological effects are dependent on the characteristics of sludge subjected to ultrasonic disintegration, but only indirectly. However, in contradiction to results of the analysis of variance, the values of disintegration indicators indicated that there were a differences in the magnitude of technological effects depending on the type of experimental device used in the process of WAS ultrasonic disintegration.

In conclusion, according to the results of statistical analysis and values of applied indicators, it could be inferred that the most promising conditions for ultrasonic pretreatment of WAS (conducting at constant energy input), are: low power, long sonication time, large surface area of the emitter.

\section{Conclusions}

This article presents the results of a comprehensive analysis of direct and technological effects of disintegration as a function of periodical changes in the characteristics of WAS, as well as technical conditions of the conducted process. In this purpose selected parameters were considered, i.e., $\mathrm{pH}$ value, $\mathrm{SCOD}, \mathrm{N}_{\mathrm{TOT}}, \mathrm{P}_{\mathrm{TOT}}$, proteins and carbohydrates concentrations, CST value, floc disruption, 
TS and VS content, before and after sludge ultrasonic disintegration or anaerobic digestion. To evaluation of direct and technological effects the commonly applied (DDCOD) and author's (IDi, IDd) indicators were used.

As a result of ultrasonic pretreatment, in the sludge or supernatant the increase of all examined parameters, except proteins and carbohydrates, were observed. Moreover, it was also showed that after completion of sludge anaerobic digestion, the increase of $\mathrm{pH}, \mathrm{N}_{\mathrm{TOT}}$ and $\mathrm{P}_{\mathrm{TOT}}$ concentration, sludge dewaterability, as well as the reduction of TS and VS content and increases of biogas production were observed. Furthermore, the conducted experiment revealed that ultrasonic disintegration reduces the content of biogenic substances in the sludge supernatant after its anaerobic digestion. This information is positive, especially with respect to necessity of recycling the leachate, generated after dehydration of sludge undergone anaerobic digestion into the technological line.

The result of $T$-Test showed that there were significant differences between the characteristics of untreated and disintegrated WAS, regardless of the technological conditions of process conducting. The above observations were related both to direct and technological effects. Whereas, Pearson's correlation confirmed, that changes in the characteristics of untreated WAS influencing effects of ultrasonic pretreatment. It was indicated that, the most important parameters, which affected the magnitude of the direct and technological effects, were: TS, VS, $\triangle \mathrm{T}>\mathrm{EPS}>\mathrm{SCOD}>\mathrm{CST}>\mathrm{N}_{\mathrm{TOT}}, \mathrm{P}_{\mathrm{TOT}}$ $>\mathrm{pH}$ and TS, VS $>\mathrm{CST}>\mathrm{N}_{\mathrm{TOT}}, \mathrm{P}_{\mathrm{TOT}}>\mathrm{pH}$, respectively. Furthermore, the analysis of variance showed, that the most significant differences between the effects obtained in various experimental devices were observed for: SCOD, $\mathrm{N}_{\mathrm{TOT}}, \mathrm{P}_{\mathrm{TOT}}, \mathrm{CST}, \Delta \mathrm{T}$ (direct effects) and CST (technological effects). It was found, that the most favorable effects of sludge ultrasonic pretreatment can be obtained conducting the process in the device characterized with low power, long sonication time and large surface area of the emitter. The results obtained in this study also confirmed the significant impact of the increase of sludge temperature during ultrasonic disintegration on the obtained effects.

Funding: This work was supported by the "DoktoRis"—Program for innovative Silesia 2007-2013, co-financed by the European Union under the European Social Found [No. 100127].

Acknowledgments: The author thank Ewa Zielewicz of Silesian University of Technology, Poland for her support throughout this study and lending the devices (disintegrators) used for experiments.

Conflicts of Interest: The author declares no conflict of interest.

\section{Appendix A}

Table A1. The results of T-Test-direct effects.

\begin{tabular}{|c|c|c|}
\hline Variables & WAS_A & WAS_B \\
\hline $\mathrm{pH}$ & 0.149546 & 0.021015 * \\
\hline SCOD & 0.000456 * & 0.000558 * \\
\hline $\mathbf{N}_{\text {TOT }}$ & $0.000060 *$ & 0.000463 * \\
\hline $\mathbf{P}_{\text {TOT }}$ & $0.000037^{*}$ & 0.000010 * \\
\hline Proteins & $0.018871 *$ & 0.478267 \\
\hline Carbohydrates & $0.000543 *$ & 0.000457 * \\
\hline CST & $0.010617^{*}$ & 0.000000 * \\
\hline $\mathbf{T}$ & $0.000540 *$ & 0.000000 * \\
\hline
\end{tabular}

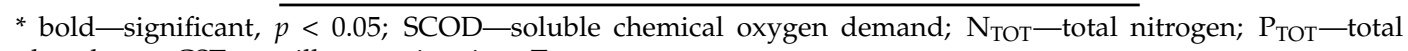
phosphorus; CST—capillary suction time; T—-temperature. 
Table A2. Pearson's correlation coefficients for the direct effects of WAS ultrasonic disintegration WK-2010).

\begin{tabular}{|c|c|c|c|c|c|c|c|}
\hline Variables & $\mathrm{pH}$ & SCOD & $\mathbf{N}_{\text {TOT }}$ & $\mathbf{P}_{\text {TOT }}$ & Proteins & Carbohydrates & CST \\
\hline $\mathrm{pH}$ & 0.00 & -0.37 & -0.17 & -0.35 & -0.30 & -0.05 & -0.01 \\
\hline SCOD & -0.32 & $-0.75^{* *}$ & -0.56 & 0.19 & 0.42 & $0.68^{* *}$ & $-0.71^{* *}$ \\
\hline $\mathbf{N}_{\text {TOT }}$ & 0.29 & $-0.72 * *$ & -0.61 & -0.10 & 0.37 & $0.85 *$ & $-0.87^{*}$ \\
\hline $\mathbf{P}_{\text {TOT }}$ & -0.51 & -0.20 & -0.74 & 0.54 & 0.70 & 0.46 & -0.39 \\
\hline Proteins & $-0.68^{* *}$ & -0.35 & -0.27 & $0.92 *$ & $0.96 *$ & 0.57 & -0.48 \\
\hline Carbohydrates & -0.21 & $-0.88 *$ & -0.43 & 0.45 & $0.79 *$ & $0.98 *$ & -0.97 * \\
\hline CST & -0.44 & $-0.65^{* *}$ & -0.60 & 0.47 & $0.66^{* *}$ & $0.75^{* *}$ & $-0.72^{* *}$ \\
\hline TS & -0.31 & $-0.85 *$ & -0.54 & 0.37 & $0.70^{* *}$ & $0.90 *$ & -0.94 * \\
\hline VS & -0.43 & $-0.83 *$ & -0.52 & 0.51 & $0.80 *$ & $0.90 *$ & $-0.92 *$ \\
\hline$\Delta \mathrm{T}$ & 0.47 & $0.84 *$ & 0.53 & -0.52 & $-0.80 *$ & $-0.87^{*}$ & $0.88 *$ \\
\hline
\end{tabular}

* bold-significant correlations, $p<0.05$; ${ }^{* *}$ non-significant correlations taken into account in statistical analysis ( $\mathrm{r} \geq 0.65)$; SCOD—soluble chemical oxygen demand; $\mathrm{N}_{\mathrm{TOT}}$ - total nitrogen; $\mathrm{P}_{\mathrm{TOT}}$ — total phosphorus; $\mathrm{CST}$ —capillary suction time; $\Delta \mathrm{T}$-temperature increase.

Table A3. Pearson's correlation coefficients for the direct effects of WAS ultrasonic disintegration (ultrasonic washer).

\begin{tabular}{|c|c|c|c|c|c|c|c|}
\hline Variables & $\mathrm{pH}$ & SCOD & $\mathbf{N}_{\text {TOT }}$ & $\mathbf{P}_{\text {TOT }}$ & Proteins & Carbohydrates & CST \\
\hline $\mathrm{pH}$ & 0.21 & 0.44 & 0.60 & -0.16 & -0.36 & -0.07 & -0.24 \\
\hline SCOD & -0.28 & 0.04 & 0.06 & 0.25 & 0.33 & $0.65^{* *}$ & -0.79 * \\
\hline $\mathbf{N}_{\text {TOT }}$ & 0.29 & 0.22 & 0.02 & -0.01 & 0.53 & $0.84 *$ & -0.58 \\
\hline $\mathbf{P}_{\text {TOT }}$ & -0.42 & -0.55 & -0.51 & 0.55 & 0.51 & 0.44 & -0.34 \\
\hline Proteins & $-0.66^{* *}$ & $-0.92 *$ & $-0.95 *$ & $0.95 *$ & $0.87 *$ & 0.58 & -0.58 \\
\hline Carbohydrates & -0.21 & -0.31 & -0.47 & 0.56 & 0.88 * & $0.98 *$ & -0.91 * \\
\hline CST & -0.48 & -0.28 & -0.31 & 0.44 & 0.57 & $0.73 * *$ & $-0.74^{* *}$ \\
\hline TS & -0.28 & -0.17 & -0.26 & 0.46 & 0.67 & $0.88 *$ & $-0.91 *$ \\
\hline VS & -0.40 & -0.32 & -0.40 & 0.60 & $0.75 * *$ & $0.89 *$ & -0.94 * \\
\hline$\Delta \mathrm{T}$ & 0.59 & 0.43 & 0.50 & $-0.71^{* *}$ & $-0.77^{*}$ & $-0.76 *$ & $0.94 *$ \\
\hline
\end{tabular}

* bold-significant correlations, $p<0.05 ;{ }^{* *}$ non-significant correlations taken into account in statistical analysis $(\mathrm{r} \geq 0.65)$; SCOD—soluble chemical oxygen demand; $\mathrm{N}_{\mathrm{TOT}}$-total nitrogen; $\mathrm{P}_{\mathrm{TOT}}$-total phosphorus; $\mathrm{CST}$-capillary suction time; $\Delta \mathrm{T}$-temperature increase.

Table A4. The results of $T$-Test-technological effects.

\begin{tabular}{|c|c|c|}
\hline Variables & WAS_A & WAS_B \\
\hline $\mathrm{pH}$ & 0.019198 * & 0.000932 * \\
\hline TS & 0.000013 * & 0.000003 * \\
\hline VS & $0.000009^{*}$ & 0.000005 * \\
\hline $\mathbf{N}_{\text {TOT }}$ & $0.000113 *$ & 0.000463 * \\
\hline $\mathbf{P}_{\text {TOT }}$ & $0.023667 *$ & 0.047379 * \\
\hline CST & 0.191863 & 0.000351 * \\
\hline
\end{tabular}

* bold—significant, $p<0.0 .05$; TS—total solids; VS—volatile solids; $\mathrm{N}_{\mathrm{TOT}}$-total nitrogen; $\mathrm{P}_{\mathrm{TOT}}$ 一 total phosphorus; CST-capillary suction time. 
Table A5. Pearson's correlation coefficients for the technological effects of WAS ultrasonic disintegration (inoculum + WAS_A).

\begin{tabular}{|c|c|c|c|c|c|c|c|}
\hline Variables & $\mathrm{pH}$ & TS & VS & $\mathbf{N}_{\text {TOT }}$ & $\mathbf{P}_{\text {TOT }}$ & CST & ${ }^{3}$ Biogas \\
\hline pH & -0.44 & 0.03 & -0.19 & -0.26 & $-0.65^{* *}$ & -0.18 & -0.42 \\
\hline TS & -0.53 & $0.98^{*}$ & $0.99 *$ & $0.92 *$ & 0.57 & $0.74^{* *}$ & $0.85 *$ \\
\hline VS & -0.34 & $0.92 *$ & $0.99 *$ & 0.97 * & $0.73^{* *}$ & $0.81 *$ & $0.94 *$ \\
\hline $\mathbf{N}_{\text {TOT }}$ & 0.20 & $-0.67^{* *}$ & $-0.75^{* *}$ & $-0.73^{* *}$ & $-0.74^{* *}$ & -0.64 & $-0.79 *$ \\
\hline $\mathbf{P}_{\text {TOT }}$ & 0.47 & 0.22 & 0.48 & 0.63 & $0.88 *$ & 0.59 & $0.74^{* *}$ \\
\hline CST & 0.61 & $-0.91 *$ & $-0.88 *$ & $-0.75^{* *}$ & -0.37 & $-0.66^{* *}$ & $-0.77 *$ \\
\hline
\end{tabular}

* bold-significant correlations, $p<0.05 ; * *$ non-significant correlations taken into account in statistical analysis $(\mathrm{r} \geq 0.65)$; Biogas — total biogas production; TS—total solids; VS—volatile solids; $\mathrm{N}_{\mathrm{TOT}}$-total nitrogen; $\mathrm{P}_{\mathrm{TOT}}$-total phosphorus; CST—capillary suction time.

Table A6. Pearson's correlation coefficients for the technological effects of WAS ultrasonic disintegration (inoculum + WAS_B).

\begin{tabular}{|c|c|c|c|c|c|c|c|}
\hline Variables & $\mathrm{pH}$ & TS & VS & $\mathbf{N}_{\text {TOT }}$ & $\mathbf{P}_{\text {TOT }}$ & CST & Biogas \\
\hline $\mathrm{pH}$ & -0.02 & -0.11 & -0.32 & -0.19 & $-0.75^{* *}$ & -0.31 & -0.43 \\
\hline TS & -0.64 & $0.99 *$ & $0.93 *$ & $0.88 *$ & 0.29 & $0.78^{*}$ & $0.76^{*}$ \\
\hline VS & -0.63 & 0.97 * & 0.99 * & 0.92 * & 0.50 & $0.87 *$ & $0.89 *$ \\
\hline $\mathbf{N}_{\text {TOT }}$ & -0.16 & -0.26 & -0.51 & -0.49 & $-0.94 *$ & -0.62 & -0.76 * \\
\hline $\mathbf{P}_{\mathrm{TOT}}$ & 0.17 & 0.15 & 0.41 & 0.31 & $0.91 *$ & 0.57 & 0.63 \\
\hline CST & 0.28 & -0.81 * & $-0.92 *$ & -0.94 * & -0.72 ** & -0.88 * & -0.93 * \\
\hline
\end{tabular}

* bold-significant correlations, $p<0.05 ; * *$ non-significant correlations taken into account in statistical analysis $(\mathrm{r} \geq 0.65)$; Biogas—-total biogas production; TS-total solids; VS-volatile solids; $\mathrm{N}_{\mathrm{TOT}}$-total nitrogen; $\mathrm{P}_{\mathrm{TOT}}$ - total phosphorus; CST—capillary suction time.

Table A7. The results of ANOVA Test-direct effects.

\begin{tabular}{ccc}
\hline Variable & Unit & $p$ Value \\
\hline pH & - & 0.233545 \\
SCOD & $\mathrm{mg} \cdot \mathrm{L}^{-1}$ & $\mathbf{0 . 0 0 0 2 7 3}$ \\
$\mathbf{N}_{\text {TOT }}$ & $\mathrm{mg} \cdot \mathrm{L}^{-1}$ & $\mathbf{0 . 0 0 0 3 8 7}$ \\
$\mathbf{P}_{\text {TOT }}$ & $\mathrm{mg} \cdot \mathrm{L}^{-1}$ & $\mathbf{0 . 0 3 1 6 1 5}$ \\
Proteins & $\mathrm{mg} \cdot \mathrm{L}^{-1}$ & 0.344718 \\
Carbohydrates & $\mathrm{mg} \cdot \mathrm{L}^{-1}$ & 0.729555 \\
CST & $\mathrm{S}$ & 0.000003 \\
$\Delta \mathrm{T}$ & ${ }^{\circ} \mathrm{C}$ & $\mathbf{0 . 0 0 0 0 0 1}$
\end{tabular}

* bold—significant correlations, $p<0.05$; SCOD—soluble chemical oxygen demand; $\mathrm{N}_{\mathrm{TOT}}$-total nitrogen; $\mathrm{P}_{\mathrm{TOT}}$ - total phosphorus; $\mathrm{CST}$-capillary suction time; $\Delta \mathrm{T}$ —temperature increase.

Table A8. The results of ANOVA Test—-technological effects.

\begin{tabular}{ccc}
\hline Variable & Unit & $p$ Value \\
\hline $\mathbf{p H}$ & - & 0.082577 \\
TS & $\mathrm{g} \cdot \mathrm{L}^{-1}$ & 0.884421 \\
VS & $\mathrm{g} \cdot \mathrm{L}^{-1}$ & 0.792592 \\
$\mathbf{N}_{\text {TOT }}$ & $\mathrm{mg} \cdot \mathrm{L}^{-1}$ & 0.324162 \\
P $_{\text {TOT }}$ & $\mathrm{mg} \cdot \mathrm{L}^{-1}$ & 0.942013 \\
CST & $\mathrm{s}$ & $\mathbf{0 . 0 0 0 8 0 1}$ \\
Biogas production & $\mathrm{cm}^{3}$ & 0.577505 \\
\hline
\end{tabular}

* bold—significant correlations, $p<0.05$, TS-total solids; VS—volatile solids; $\mathrm{N}_{\mathrm{TOT}}$-total nitrogen; $\mathrm{P}_{\mathrm{TOT}}$-total phosphorus; CST—capillary suction time. 


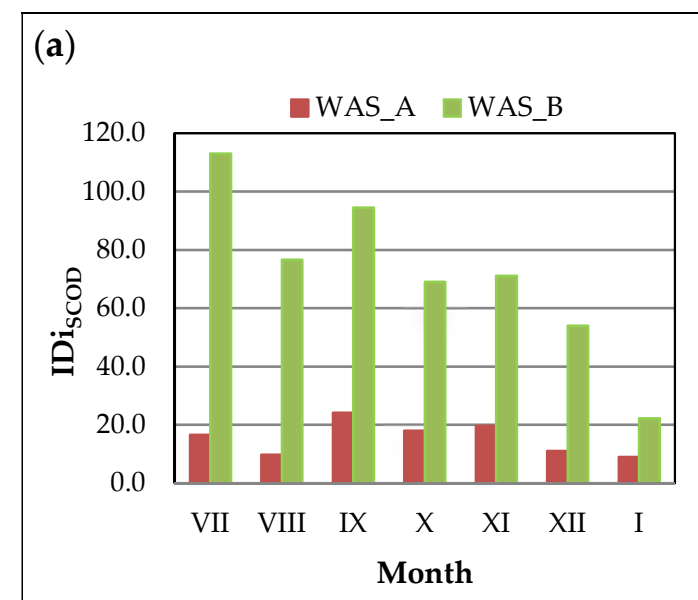

(d)

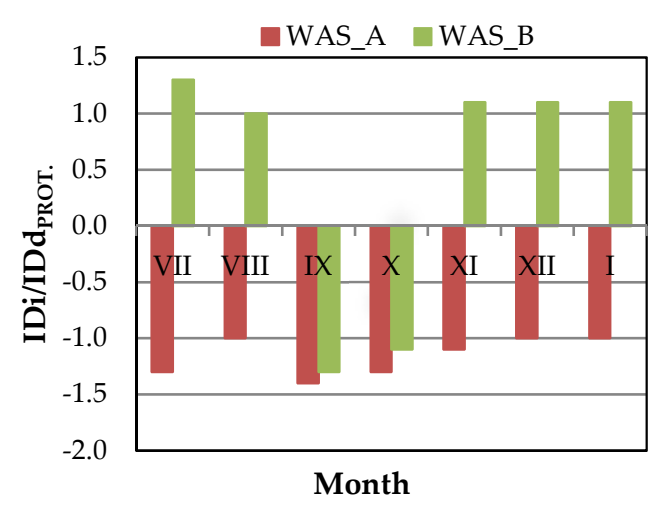

(b)

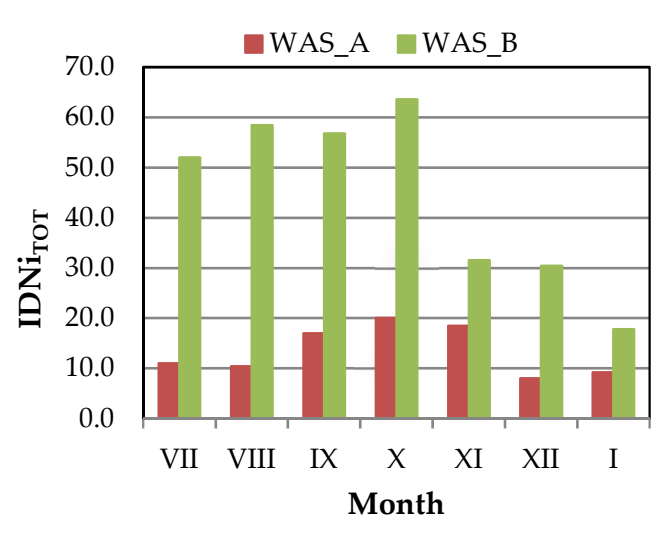

(e)

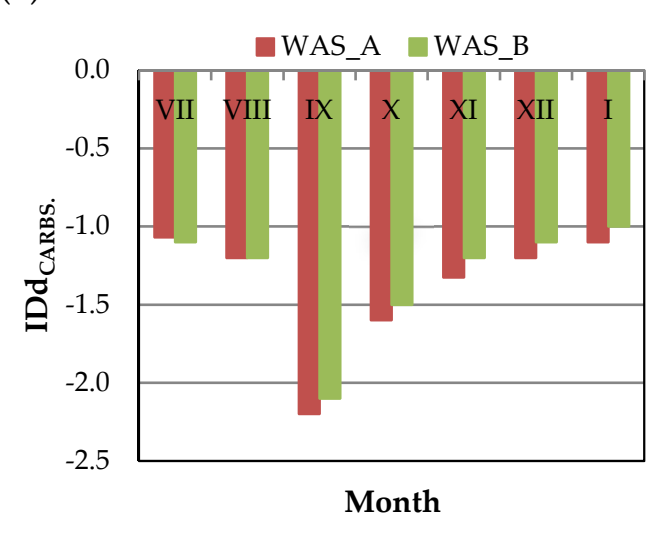

(c)

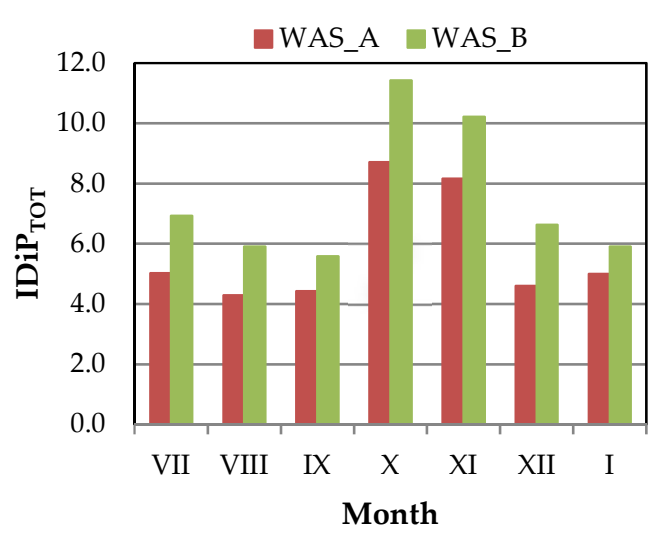

(f)

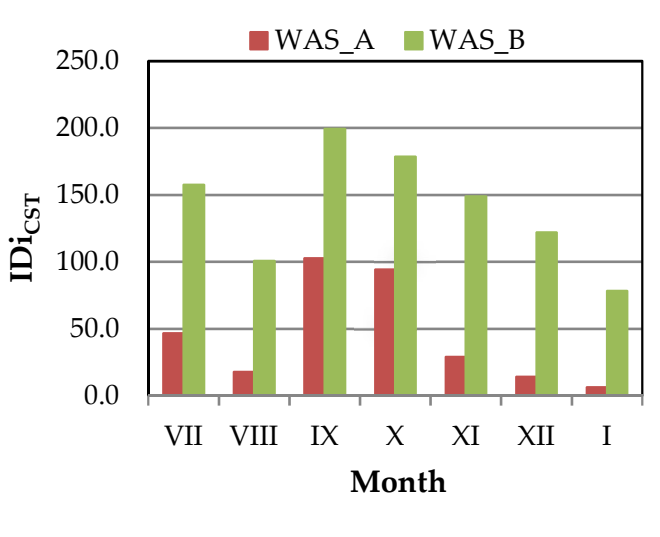

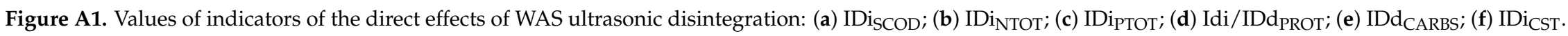
WAS_A—waste activated sludge after pretreatment in the WK-2010; WAS_B—waste activated sludge after pretreatment in the ultrasonic washer. 

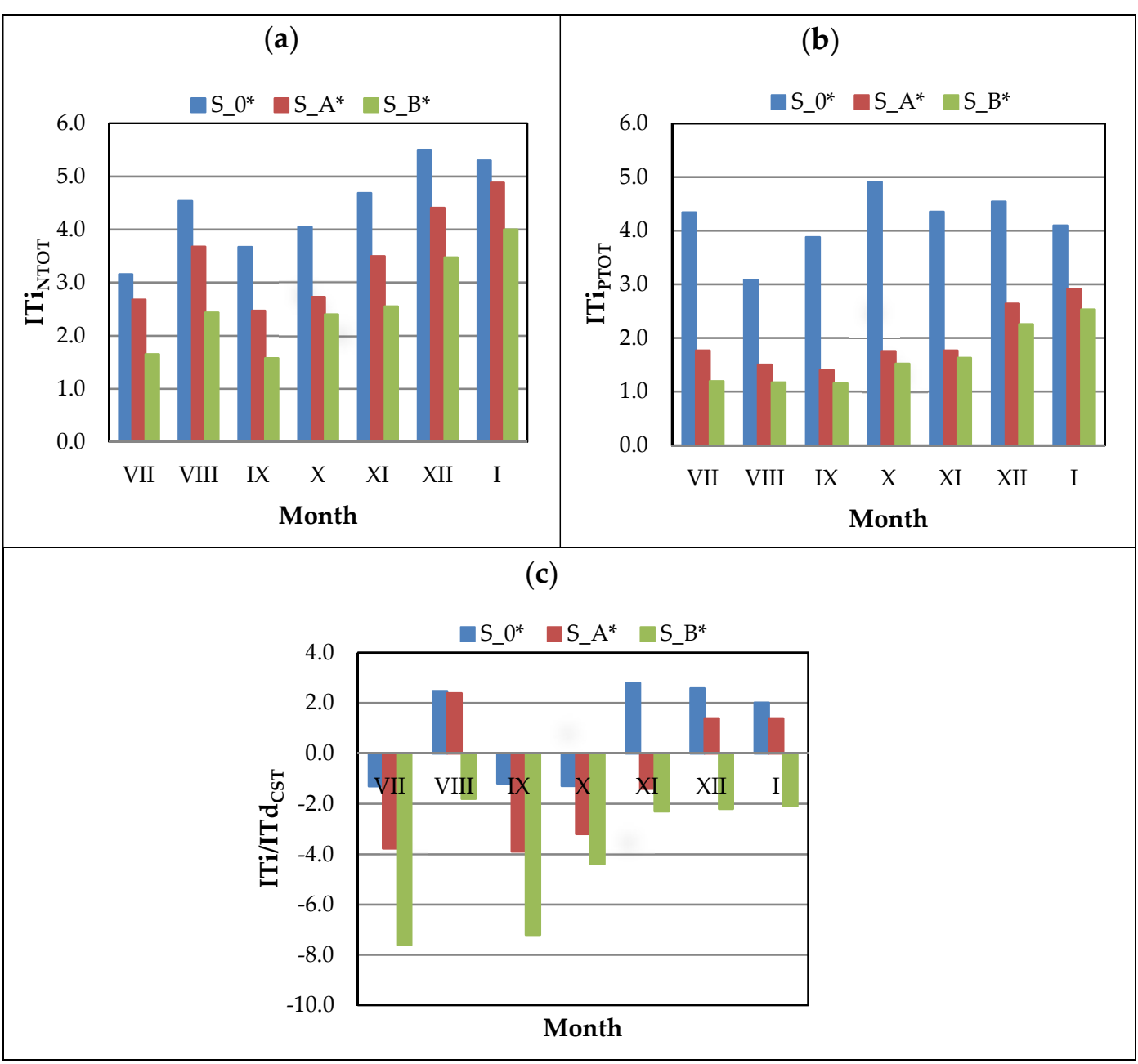

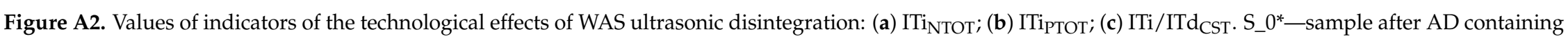
inoculum and original sludge; S_A*—sample after AD containing inoculum and WAS_A; S_B*_sample after AD containing inoculum and WAS_B. 


\section{References}

1. Council Directive 91/271/EEC of 21 May 1991 Concerning Urban Waste-Water Treatment. Available online: https:/ / eur\$-\$lex.europa.eu/legal\$-\$content/EN/TXT/PDF/?uri=CELEX:31991L0271\&from=EN (accessed on 30 May 1991).

2. Pilli, S.; Bhunia, P.; Yan, S.; LeBlanc, R.J.; Tyagi, R.D.; Surampalli, R.Y. Ultrasonic pretreatment of sludge: A review. Ultrason. Sonochem. 2011, 18, 1-18. [CrossRef] [PubMed]

3. Lippert, T.; Bandelin, J.; Musch, A.; Drewes, J.E.; Koch, K. Energy-positive sewage sludge pre-treatment with a novel ultrasonic flatbed reactor at low energy input. Bioresour. Technol. 2018, 264, 298-305. [CrossRef] [PubMed]

4. Milieu Ltd. Final report for the European Commission, Milieu Ltd, WRc, RPA, DG Environment 2008. Environmental, Economic and Social Impacts of the Use of Sewage Sludge on Land. Final Report, Part II: Project Interim (DGENV.G.4/ETU/2008/0076r.). Available online: http:/ / ec.europa.eu/environment/ archives/waste/sludge/pdf/part_ii_report.pdf (accessed on 29 April 2015).

5. Simonetti, M.; Rossi, G.; Cabbai, V.; Goi, D. Tests on the effect of ultrasonic treatment on two different activated sludge waste. Environ. Prot. Eng. 2014, 40, 23-34.

6. Le, N.T.; Julcour-Lebigue, C.; Delmas, H. An executive review of sludge pretreatment by sonication. J. Environ. Sci. 2015, 37, 139-153. [CrossRef] [PubMed]

7. Skórkowski, Ł.; Zielewicz, E.; Kawczyński, A.; Gil, B. Assessment of excess sludge ultrasonic, mechanical and hybrid pretreatment in relation to the energy parameters. Water 2018, 10, 551. [CrossRef]

8. Koch, K.; Lippert, T.; Hauck Sabadini, N.; Drewes, J.E. Tube reactors as a novel ultrasonication system for trouble-free treatment of sludges. Ultrason. Sonochem. 2017, 37, 464-470. [CrossRef] [PubMed]

9. Gonzalez, A.; Hendriks, A.T.W.M.; van Lier, J.B.; de Kreuk, M. Pre-treatments to enhance the biodegradability of waste activated sludge: Elucidating the rate limiting step. Biotechnol. Adv. 2018, 36, 1431-1469. [CrossRef] [PubMed]

10. Lizama, A.C.; Figueiras, C.C.; Herrera, R.R.; Pedreguera, A.Z.; Espinoza, J.E.R. Effects of ultrasonic pretreatment on the solubilization and kinetic study of biogas production from anaerobic digestion of waste activated sludge. Int. Biodeterior. Biodegrad. 2017, 123, 1-9. [CrossRef]

11. Zielewicz, E. Effects of ultrasonic disintegration of excess sewage sludge. Top Curr. Chem. 2016, 374, 149-174.

12. Cimochowicz-Rybicka, M. Minimization of Sewage Sludge Production-European Trends and Selected Technologies. Available online: https://www.kth.se/polopoly_fs/1.651120!/JPSU18P12.pdf (accessed on 10 October 2018).

13. Tytła, M.; Zielewicz, E. The impact of temporal variability of excess sludge characteristics on the effects obtained in the process of its ultrasonic disintegration. Environ. Technol. 2018, 39, 1-13. [CrossRef] [PubMed]

14. Müller, J. Mechanischer Klärschlammaufschluß, Schriftenereihe "Berichte aus der Verfahrenstechnik". Ph.D. Thesis, der Fakultät für Maschinenbau und Elektrotechnik der, Universität Braunschweig. Shaker Verlag, Aachen, Germany, 1996.

15. Wang, F.; Wang, Y.; Ji, M. Mechanisms and kinetics models for ultrasonic waste activated sludge disintegration. J. Hazard. Mater. 2005, 123, 145-150. [CrossRef] [PubMed]

16. Tiehm, A.; Nickel, K.; Zellhorn, M.; Neis, U. Ultrasound waste activated sludge disintegration for improving anaerobic stabilization. Water Res. 2001, 35, 2003-2009. [CrossRef]

17. Feng, X.; Lei, H.Y.; Deng, J.C.; Yu, Q.; Li, H. Physical and chemical characteristics of waste activated sludge treated ultrasonically. Chem. Eng. Process. 2009, 48, 187-194. [CrossRef]

18. Erden, G.; Filibeli, A. Ultrasonic pre-treatment of biological sludge: Consequences for disintegration, anaerobic biodegradability, and filterability. J. Chem. Technol. Biotechnol. 2010, 85, 145-150. [CrossRef]

19. Cho, S.K.; Shin, H.S.; Kim, D.H. Waste activated sludge hydrolysis during ultrasonication: Two-step disintegration. Bioresour. Technol. 2012, 121, 480-483. [CrossRef] [PubMed]

20. Ruiz-Hernando, M.; Martinez-Elorza, G.; Labanda, J.; Llorens, J. Dewaterability of sewage sludge by ultrasonic, thermal and chemical treatments. Chem. Eng. J. 2013, 230, 102-110. [CrossRef]

21. Tomczak-Wandzel, R.; Ofverstrom, S.; Dauknys, R.; Medrzycka, K. Effect of disintegration pretreatment of sewage sludge for enhanced anaerobic digestion. In The 8th International Conference "Environmental Engineering": Selected Papers, Vilnius, Lithuania, 19-20 May 2011; Čygas, D., Froehner, K.D., Eds.; Vilnius Gediminas Technical University: Vilnius, Lithuania, 2011; pp. 679-683. 
22. Zielewicz, E.; Tytła, M. Effects of ultrasonic disintegration of excess sludge obtained in disintegrators of different constructions. Environ. Technol. 2015, 36, 2210-2216.

23. Zielewicz, E. Effects of ultrasonic disintegration of excess sewage sludge. Appl. Acoust. 2016, 103, $182-189$. [CrossRef]

24. Tytła, M.; Zielewicz, E. The effect of ultrasonic disintegration process conditions on the physicochemical characteristics of excess sludge. Arch. Environ. Prot. 2016, 42, 19-26. [CrossRef]

25. Karapanagiotis, N.K.; Rudd, T.; Sterritt, R.M.; Lester, J.N. Extraction and characterisation of extracellular polymers in digested sewage sludge. J. Chem. Technol. Biotechnol. 1989, 44, 107-120. [CrossRef]

26. Raszka, A.; Surmacz-Górska, J.; Żabczyński, S. Extracellular polymeric substances in the nitrifying activated sludge. ACEE 2010, 3, 115-119.

27. Polish Committee for Standardization. Characterization of Sludge-Determination of pH-Value; PN-EN 12176:2004; Polish Committee for Standardization: Warszawa, Poland, 2004.

28. Polish Committee for Standardization. Characteristics of Sewage Sludge, Determination of Dry Residue and Water Content; PN-EN 12880:2004; Polish Committee for Standardization: Warszawa, Poland, 2004.

29. Polish Committee for Standardization. Characteristics of Sewage Sludge, Determination of Loss on Ignition of Dry Matter; PN-EN 12879:2004; Polish Committee for Standardization: Warszawa, Poland, 2004.

30. International Organization for Standardization. Water Quality-Determination of the Chemical Oxygen Demand Index (ST-COD)-Small-Scale Sealed Tube Method; ISO 15705:2002; International Organization for Standardization: Geneva, Switzerland, 2002.

31. International Organization for Standardization. Water Quality-Determination of Nitrogen-Part 1: Method using Oxidative Digestion with Peroxodisulfate; ISO 11905-1:1997; International Organization for Standardization: Geneva, Switzerland, 1997.

32. International Organization for Standardization. Water Quality-Determination of Phosphorus-Ammonium Molybdate Spectrometric Method; ISO 6878:2004; International Organization for Standardization: Geneva, Switzerland, 2004.

33. Lowry, O.; Rosebrough, N.; Farr, A.L.; Randall, R. Protein measurement with the Folin phenol reagent. J. Biol. Chem. 1951, 193, 265-275. [PubMed]

34. Dubois, M.; Gilles, K.A.; Hamilton, J.K.; Reber, P.A.; Smith, F. Colorimetric method for determination of sugars and related substances. Anal. Chem. 1956, 28, 350-356. [CrossRef]

35. Polish Committee for Standardization. Characterization of Sludges-Filtration Properties_Part 3: Capillary Suction Time (CST); PN-EN 14701-1:2007; Polish Committee for Standardization: Warszawa, Poland, 2004.

36. Neis, U.; Nickel, K.; Tiehm, A. Enhancement of anaerobic sludge digestion by ultrasonic disintegration. Water Sci. Technol. 2000, 42, 73-80. [CrossRef]

37. German Institute for Standardisation. German Standard Methods for the Examination of Water, Waste Water and Sludge; Sludge and Sediments (Group S); Determination of the Amenability to Anaerobic Digestion (S 8); DIN 38414-8:1985-06; German Institute for Standardization: Berlin, Germany, 1985.

38. Gündüz, Ç. Ultrasonic Disintegration of Sewage Sludge. Master's Thesis, Dokuz Eylül University, Izmir, Turkey, 2009.

39. Zhang, P.; Zhang, G.; Wang, W. Ultrasonic treatment of biological sludge: Floc disintegration, cell lysis and inactivation. Biores. Technol. 2007, 98, 207-210. [CrossRef] [PubMed]

40. Sahinkaya, S. Disintegration of municipal waste activated sludge by simultaneous combination of acid and ultrasonic pretreatment. Process Saf. Environ. Prot. 2015, 93, 201-205. [CrossRef]

41. Show, K.Y.; Mao, T.; Lee, D.J. Optimization of sludge disruption by sonication. Water Res. 2007, 41, $4741-4747$. [CrossRef] [PubMed]

42. Zhou, J.; Zheng, G.; Zhang, X.; Zhou, L. Influences of extracellular polymeric substances on the dewaterability of sewage sludge during bioleaching. PLoS ONE 2014, 9, e102688. [CrossRef] [PubMed]

43. Houghton, J.I.; Quarmby, J.; Stephenson, T. Municipal wastewater sludge dewaterability and the presence of microbial extracellular polymer. Water Sci. Technol. 2011, 44, 373-379. [CrossRef]

44. Vesilind, P.A.; Davis, H.A. Using the CST device for characterizing sludge dewaterability. Water Sci. Technol. 1988, 20, 203-205. [CrossRef] 
45. Tomczak-Wandzel, R.; Mędrzycka, K.; Cimochowicz-Rybicka, M. Wpływ dezintegracji ultradźwiękowej na przebieg fermentacji metanowej. Available online: https://mostwiedzy.pl/pl/publication/wplywdezintegracji-ultradzwiekowej-na-przebieg-fermentacji-metanowej-the-effect-of-ultrasonic-disin,1105421 (accessed on 18 October 2018).

46. Braguglia, C.M.; Gianico, A.; Mininni, G. Comparison between ozone and ultrasound disintegration on sludge anaerobic digestion. J. Environ. Manag. 2012, 95, S139-S143. [CrossRef] [PubMed]

47. Xu, H.; He, P.; Yu, G.; Shao, L. Effect of ultrasonic pretreatment on anaerobic digestion and its sludge dewaterability. J. Environ. Sci. 2011, 23, 1472-1478. [CrossRef]

48. Martínez, E.; Rosas, J.; Morán, A.; Gómez, X. Effect of ultrasound pretreatment on sludge digestion and dewatering characteristics: Application of particle size analysis. Water 2015, 7, 6483-6495. [CrossRef]

49. Cimochowicz-Rybicka, M.; Rybicki, S. Application of respirometric tests for assessment of methanogenic bacteria activity in wastewater sludge processing. J. Ecol. Eng. 2013, 14, 44-52. [CrossRef]

50. Salihu, A.; Alam, M.D. Pretreatment methods of organic wastes for biogas production. J. Appl. Sci. 2016, 16, 124-137. [CrossRef]

(C) 2018 by the author. Licensee MDPI, Basel, Switzerland. This article is an open access article distributed under the terms and conditions of the Creative Commons Attribution (CC BY) license (http:/ / creativecommons.org/licenses/by/4.0/). 